\title{
Methane growth rate estimation and its causes in western Canada using satellite observations
}

\author{
S. M. Nazrul Islam ${ }^{1, *}, \dagger$, Peter L. Jackson ${ }^{1}$, Colm Sweeney ${ }^{2}$, Kathryn McKain ${ }^{2,3}$, Christian \\ Frankenberg $^{4,5}$, Ilse Aben ${ }^{6}$, Robert. J. Parker ${ }^{7,8}$, Hartmut Boesch ${ }^{7,8}$, and Debra Wunch ${ }^{9}$
}

${ }^{1}$ Natural Resources and Environmental Studies Institute, University of Northern British

Columbia, Prince George, British Columbia V2N 4Z9, Canada.

${ }^{2}$ National Oceanic and Atmospheric Administration, Global Monitoring Laboratory, Boulder, Colorado 80305-3328, USA.

${ }^{3}$ Cooperative Institute for Research in Environmental Sciences, University of Colorado, Boulder, Colorado, 80309, USA.

${ }^{4}$ California Institute of Technology, Division of Geological and Planetary Sciences, Pasadena, California, USA.

${ }^{5}$ Jet Propulsion Laboratory, California Institute of Technology, Pasadena, California 91109, USA.

${ }^{6}$ SRON Netherlands Institute for Space Research, 3584 CA Utrecht, the Netherlands.

${ }^{7}$ National Centre for Earth Observation, University of Leicester, UK.

${ }^{8}$ Earth Observation Science, School of Physics and Astronomy, University of Leicester, UK.

${ }^{9}$ Department of Physics, University of Toronto, Toronto, Ontario M5S 1A7 Canada.

*Corresponding author: S M Nazrul Islam (nazrul.islam@noaa.gov; smnazrul818@gmail.com). $\dagger$ Dr. Islam was doctoral student at University of Northern British Columbia while conducting most of this study. Present affiliation: National Oceanic and Atmospheric Administration, Global Monitoring Laboratory, Boulder, Colorado 80305-3328, USA; \&

Cooperative Institute for Research in Environmental Sciences, University of Colorado, Boulder, Colorado, 80309, USA.

\section{Key Points:}

- Methane growth rate in western Canada was positive during 2009-2013, fluctuated afterwards, resulting in an undetectable trend after 2013

- Methane growth seemed to be related to emissions from oil and gas industries

- Average growth rate (15.43 $\pm 8.19 \% / y r)$ between $2009-2013$ likely reflects a trend in oil and gas $\mathrm{CH}_{4}$ emissions in western Canada

This article has been accepted for publication and undergone full peer review but has not been through the copyediting, typesetting, pagination and proofreading process, which may lead to differences between this version and the Version of Record. Please cite this article as doi: 10.1029/2020JD033948. 


\begin{abstract}
In this study, the GOSAT Proxy Retrieval (v9.0) data product of column-averaged dry-air mole fractions of atmospheric methane $\left(\mathrm{XCH}_{4}\right)$ for the period 2009-2019 were analyzed to detect methane $\left(\mathrm{CH}_{4}\right)$ trends in the three western Canadian provinces where oil and gas development activities have changed significantly over the last decade. Although we found statistically significant increasing $\mathrm{XCH}_{4}$ trends in all subdomains (northeast British Columbia-NE, Alberta$\mathrm{AB}$, southern Saskatchewan-SK), $\mathrm{XCH}_{4}$ trends are not higher than the background trend $(7.25 \pm 0.30 \mathrm{ppb} / \mathrm{yr})$ and enhancement trends $(\triangle \mathrm{XCH}$, after removing the background quantity) are not detectable at any subdomain during 2009-2019. For further insight into trends in all subdomains, we divided the whole period (2009-2019) into two shorter periods (2009-2013 and 2014-2019) and estimated trends. We found $\mathrm{XCH}_{4}$ trends are higher than background trends particularly in the $\mathrm{AB}$ and SK subdomains during 2009-2013, and their $\Delta \mathrm{XCH}_{4}$ trends are positive and also marginally statistically significant. However, we do not find any detectable $\triangle \mathrm{XCH}_{4}$ trend if we consider either long-term (2009-2019) or the second shorter period (20142019), suggesting local emission sources are dominating year to year fluctuation. From the source attribution analysis, we found both wetland and oil and gas sectors are controlling the $\mathrm{CH}_{4}$ growth rate in western Canada, but the oil and gas sector is the dominant driver in $\mathrm{NE}$ and SK subdomains. We also found the satellite-based average $\triangle \mathrm{XCH}_{4}$ trend $(15.43 \pm 8.19 \% / \mathrm{yr})$ between 2009-2013 likely reflects a trend in oil and gas $\mathrm{CH}_{4}$ emissions in $\mathrm{AB}$ and $\mathrm{SK}$ for the same period.
\end{abstract}

\title{
1 Introduction
}

The globally averaged atmospheric methane dry air mole fraction $\left(\mathrm{CH}_{4}\right)$ was $722.0 \pm 25.0$ ppb in 1750 (IPCC, 2013), 1644.7 $\pm 0.7 \mathrm{ppb}$ in 1984, but by 2019 it was $1866.6 \pm 0.6 \mathrm{ppb}$ (Dlugokencky, 2021) with global total emissions ranging from 572 to $737 \mathrm{Tg} / \mathrm{yr}$ from 2008-2017 (Saunois et al., 2020), depending on the estimation methodology (Ganesan et al., 2019). Since pre-industrial times (1750) $\mathrm{CH}_{4}$ emissions have contributed $0.97 \mathrm{~W} / \mathrm{m}^{2}$ of global radiative forcing, which is second only to carbon dioxide $\left(\mathrm{CO}_{2}, 1.70 \mathrm{~W} / \mathrm{m}^{2}\right)$ among all greenhouse gases (GHGs, IPCC, 2013). Major anthropogenic sources of atmospheric $\mathrm{CH}_{4}$ are oil and gas systems, coal mining, livestock (enteric fermentation and manure management), and waste (landfills and wastewater treatment); wetlands are the dominant natural source. Currently, 50-60\% of the total $\mathrm{CH}_{4}$ emissions are from anthropogenic sources (Saunois et al., 2016, 2020). Direct atmospheric $\mathrm{CH}_{4}$ measurements with sufficient spatial coverage to calculate the global average began in 1983, and since that period a series of changes in the $\mathrm{CH}_{4}$ growth rate have been observed (Dlugokencky, 2021; IPCC, 2013). From the early 1980s to 1998 the growth of $\mathrm{CH}_{4}$ decreased, was stable during 1999 to 2006, and then increased again from 2007 to the present (Dlugokencky, 2021; Dlugokencky et al., 2011; Nisbet et al., 2014, 2016). It is now well documented that the $\mathrm{CH}_{4}$ content in the atmosphere has increased at most latitudes since 2007, although the growth rate fluctuates from year to year (Dlugokencky, 2021; Nisbet et al., 2016). The global averaged dry air mole fraction of $\mathrm{CH}_{4}$ in the atmosphere increased by $7.16 \pm 0.60$ $\mathrm{ppb} / \mathrm{yr}$ for the period 2007-2018, but the growth rate was slower for the earlier part (2007-2013, $5.70 \pm 0.57 \mathrm{ppb} / \mathrm{yr})$ compared to the rate over more recent years $(2014-2018,9.21 \pm 0.64 \mathrm{ppb} / \mathrm{yr})$ with peak growth in 2014 (12.71 $\pm 0.43 \mathrm{ppb} / \mathrm{yr}$ ), indicating a second step of growth (Mikaloff Fletcher \& Schaefer, 2019; Nisbet et al., 2019). There have been many recent studies aimed at

This article is protected by copyright. All rights reserved. 
identifying possible reasons for the stabilization period (1999-2006) and for the renewed growth period after 2007. However, a broadly-accepted explanation has not yet been found because the renewed growth period is characterized by a source-sink imbalance of only $3.0 \%$ and there are large uncertainties in the emissions from individual source sectors (Turner et al., 2019). However, possible explanations could be increased fossil fuel emissions (Turner et al., 2016), microbial sources (Kai et al., 2011; Levin et al., 2012; Schwietzke et al., 2016), wetlands (Bergamaschi et al., 2013; Nisbet et al., 2016; Pison et al., 2013), and changes in the OH sink (Rigby et al., 2017; Turner et al., 2017).

Canada's government-reported total annual $\mathrm{GHG}$ and $\mathrm{CH}_{4}$ emissions between 2005 and 2018 are shown in Fig. 1. The GHG emissions fluctuated between 2005 and 2008, dropped in 2009, and thereafter gradually increased until 2014, dropping again in 2015 and 2016. Afterwards it increased by $1.1 \%$ in 2017 and 3.3\% in 2018 relative to 2016 (NIR, 2020; Fig. 1a). In 2018, Canada's total GHG emissions were reported to be 729.3 megatonnes of $\mathrm{CO}_{2}$ equivalent ( $\mathrm{Mt} \mathrm{CO}_{2}$ eq), similar to the 2005 emissions, but a 7.2\% increase from 2009 levels (GC, 2020a; NIR, 2020). According to the inventories, Canada's three western provinces (British Columbia, Alberta and Saskatchewan) are responsible for 57\% of 2018 national total GHG emissions (Fig. 1a) and they accounted for $70 \%$ of 2018 national total $\mathrm{CH}_{4}$ emissions (3.7 Mt) (Fig. 1b), primarily because of oil and gas production (Fig. 1d) and their associated operations (CER, 2020). Among all IPCC $\mathrm{CH}_{4}$ emission sectors, fugitive emissions from the energy sector contributed nearly $43 \%$ (1.6 Mt) of 2018 national total $\mathrm{CH}_{4}$ emissions, and these three provinces were responsible for $95 \%$ of 2018 national total fugitive emissions (GC, 2020a; NIR, 2020; Fig. 1c). Fugitive emission refers to the intentional or unintentional releases of GHGs from the production, processing, transmission, storage and delivery of fossil fuels (NIR, 2020). A recent study suggested that fugitive emissions in Alberta and Saskatchewan are underestimated in the government inventory (Chan et al., 2020). Fugitive energy sector $\mathrm{CH}_{4}$ emissions in the three western provinces have also fluctuated, especially after 2009, while emissions from other sectors have not varied as much (Fig. 1c and Fig. S1). Emissions from the agriculture and waste sectors are relatively low (Fig. S1), and they are consistently quantified (Chan et al., 2020). The variations of fugitive emissions might be associated with energy production (Fig. 1d) or annual new well count variations (Fig. S2). Besides the IPCC sectors, natural emissions, especially seasonally and interannually variable emissions from wetlands are also important in this area (Chan et al., 2020; Bloom et al., 2017) (Fig. S1). Since $\mathrm{CH}_{4}$ is such a potent GHG and the oil and gas sector is the largest contributor to $\mathrm{CH}_{4}$ emissions in Canada, the Government of Canada (GC) set targets to reduce $\mathrm{CH}_{4}$ emissions from the oil and gas sector by 40-45\% from 2012 levels by 2025 (ECCC, 2017). Reported national total fugitive $\mathrm{CH}_{4}$ emissions in 2018 (1.6 Mt) were only a $\sim 6.0 \%$ reduction from the 2012 levels of $1.7 \mathrm{Mt}$ (GC, 2020a).

Recently, Bruhwiler et al. (2017) and Lan et al. (2019) re-examined previously reported large increases in US oil and gas sector $\mathrm{CH}_{4}$ emissions using the vertical gradient of observed $\mathrm{CH}_{4}$ mole fractions as a proxy for surface emission changes; they could not confirm the high emissions reported by Turner et al. (2016), which investigated US $\mathrm{CH}_{4}$ emissions trends with satellite data. One reason for the potential overestimation of US $\mathrm{CH}_{4}$ emissions in Turner et al. (2016) is the poor representation of background $\mathrm{XCH}_{4}$ in the background domain. Bruhwiler et al. (2017) also pointed out that the vertical gradient of $\mathrm{CH}_{4}$ mole fraction is a more sensitive indicator of surface emissions than horizontal gradients. Note that since satellite-based methane is a column-averaged dry air mole fraction, it is labelled and hereafter expressed as " $\mathrm{XCH}_{4}$ ".

This article is protected by copyright. All rights reserved. 
Since in situ measurements such as those from aircraft, are not column averages, they are labelled as " $\mathrm{CH}_{4}$ ". A recent study (Sheng et al., 2018) examined $\mathrm{XCH}_{4}$ trends over Canada, the US and Mexico using 7 years (2010-2016) of Greenhouse Gases Observing Satellite (GOSAT) data products, addressing major concerns pointed out by Bruhwiler et al. (2017). Sheng et al. (2018) were unable to demonstrate that atmospheric $\mathrm{XCH}_{4}$ trends in Canada were associated with oil and gas emissions, rather they found wetland-driven year to year variability. They argued that GOSAT observations over Canadian oil and gas dominated regions were too sparse for oil and gas emission trend detection. Their requirement of at least eight annual observations in each bin $\left(0.5^{\circ} \times 0.5^{\circ}\right.$ grid resolution $)$ for their local background-based annual mean enhancement quantification, contributes to sparse data by ignoring some valid GOSAT observations over the large Canadian oil and gas industrial area. Furthermore, the GOSAT XCH 4 product has data gaps both spatially and temporarily (no data during January, November and December in western Canada, Table S1 and S2). Importantly, a recent study (Chan et al., 2020) using hourly $\mathrm{CH}_{4}$ observations showed $\mathrm{CH}_{4}$ temporal variabilities last only 2 to 5 days and are due to local anthropogenic sources and prevailing meteorological synoptic conditions. Those episodic events could be diminished in the summer months partially due to active convection resulting in a high planetary boundary layer (PBL), and also due to wetland $\mathrm{CH}_{4}$ emissions which is largest in the mid-summer in Alberta and Saskatchewan (Chan et al., 2020). Considering all these facts we argued the annual mean enhancement calculation approach at $0.5^{\circ} \times 0.5^{\circ}$ grid resolution is limiting the trend detection in the Sheng et al. (2018) analysis. In our analysis we attempted to quantify monthly enhancements in larger domain to capture $\mathrm{CH}_{4}$ variabilities that would consequently improve the trend detection for source attribution.

In this study we used data from the Thermal And Near infrared Sensor for carbon Observation - Fourier Transform Spectrometer (TANSO-FTS, Kuze et al., 2009, 2016) on board GOSAT for the period 2009-2019 to detect trends in atmospheric $\mathrm{XCH}_{4}$ over the three western Canadian provinces (British Columbia, Alberta and Saskatchewan) where oil and gas development activities have changed over the last decade and wetland $\mathrm{CH}_{4}$ emissions are also significant. We also quantified enhancements $\left(\Delta \mathrm{XCH}_{4}\right)$ and their trends after removing the appropriate background quantity. Finally, we derived the major causes of the $\Delta \mathrm{XCH}_{4}$ above background by comparing annual mean $\triangle \mathrm{XCH}_{4}$ with the annual mean source specific emissions for the corresponding time and location. Before performing source attribution analysis, we also used in-situ vertical profile measurements of $\mathrm{CH}_{4}$ up to $8 \mathrm{~km}$ above sea level (asl) at three stations located in western Canada (one is in North Dakota, US, see section 2.2) from the NOAA Global Greenhouse Gas Reference Network's (GGGRN) aircraft program (Cooperative Global Atmospheric Data Integration Project, 2020; Sweeney et al., 2015) to evaluate the satellite data products, and also the trends estimated from satellite data. It is important to note that trends between satellite data and aircraft measurements should be in reasonable agreement because $\mathrm{CH}_{4}$ sources are at the surface and sinks are mostly in the troposphere, and stratospheric effects on the $\mathrm{XCH}_{4}$ total column are relatively less (Kivimäki et al., 2019). However, $\mathrm{XCH}_{4}$ might be affected by transport in addition to local fluxes, therefore, these two different data products are not directly comparable at small time scales such as seasonal cycles (Kivimäki et al., 2019). The paper is structured as follows: in section 2 we introduce our study area, as well as the satellite and aircraft flask data products. The results from satellite and aircraft data products are presented and discussed in section 3. Before describing any new results we also introduce the relevant methods in the appropriate section, instead providing an independent method section. Satellite

This article is protected by copyright. All rights reserved. 
data validation is also described at the beginning of section 3. A summary and conclusions are given in section 4 .

\section{Study area and data sources}

\subsection{Study area}

This study analyzes $\mathrm{CH}_{4}$ trends using satellite and aircraft data products over Canada's three western provinces (British Columbia, Alberta, Saskatchewan). These provinces cover 2.1 million square kilometers, almost $24 \%$ of Canada's land area. They are bordered by two territories, Yukon, Northwest Territories to the north; the province of Manitoba to the east; by the states of Washington, Idaho, Montana and North Dakota to the south; and Alaska and the Pacific Ocean to the west (Fig. 2). Approximately 9.8 million people, roughly $28 \%$ of the Canadian population, live in this area, with the majority in urban areas dominated by major cities including Vancouver, Victoria, Kelowna, Calgary, Edmonton, Saskatoon, and Regina (Statistics Canada, 2017a, 2017b, 2017c, 2017d). Western Canada's economic growth is mostly based on the natural resources sector that includes mining, forestry, oil and gas, and agriculture, and contributes significantly to the overall Canadian economy (WD, 2018).

Emissions inventories (Fig. 1; S1 and S2) and previous studies (Chan et al., 2020; Sheng et al., 2018) reported that fugitive emissions from the oil and gas sector, and wetland emissions have large variability in each province of western Canada. To better understand $\mathrm{CH}_{4}$ dry air mole fractions and their spatial and temporal variability due to local emission sources, the three provinces are subdivided into three subdomains. These subdomains are constructed in such a way that each is in one province and covers the major oil and gas industries of that province. This partitioning approach allowed us to cover spatial distribution of major anthropogenic sources and also wetland areas. The NE subdomain is in northeast BC, AB is in Alberta, and SK is in southern Saskatchewan (Fig. 2). Figure 2 shows the geographical distribution of western Canadian oil and gas facilities that report GHG emissions of $10 \mathrm{Kt} \mathrm{CO}_{2}$ eq or more in 2018 (GC, 2020b) as well as historical oil and gas well locations in Canada and the neighboring states of Montana and North Dakota. Note, we found 770 facilities (out of 1078 in the three western provinces) are oil and gas types, resulting in about $\sim 75 \%$ of the total facilities that reported $\mathrm{CH}_{4}$ emissions. It is evident that the largest $\mathrm{CH}_{4}$ emitting facilities are located in the subdomains (Fig. 2). We also created one domain (MN) covering Montana and North Dakota for $\mathrm{CH}_{4}$ trend analysis. The purpose of including the MN subdomain for trend analysis is due to the fact that MN subdomain also has dense oil and gas wells, is located close to the SK subdomain and importantly has the DND aircraft measurement site. Therefore we can evaluate satellite based trends with aircraft measurements in that subdomain. Our chosen background subdomain (BK) does not contain any major anthropogenic sources of $\mathrm{CH}_{4}$ particularly from oil and gas type facilities (Fig. 2). Although the southwestern part of the BK subdomain contains Pacific Ocean, GOSAT ocean glint mode $\mathrm{XCH}_{4}$ observations are not considered in the analysis. Since we used monthly mean $\mathrm{XCH}_{4}$ in the $\mathrm{BK}$ subdomain for the enhancement quantification $\left(\triangle \mathrm{XCH}_{4}\right)$, we also analyze back-trajectories on each day of 2018. We assumed back trajectories patterns of other years would be similar. The back-trajectories were computed at one receptor site (5500 m above ground) in the BK subdomain using NOAA's HYbrid Single-Particle Lagrangian Integrated Trajectory (HYSPLIT) model (Stein et al., 2015). At this receptor location 10 day backtrajectories at an hourly interval during 2100 UTC time (GOSAT observation time) of each day

This article is protected by copyright. All rights reserved. 
were computed (Kirk Thoning, personal communication). Monthly analysis of the 2018 backtrajectories demonstrated the BK subdomain is dominated by westerly winds except for a few days in March, May and June (Fig. S3), confirming that the BK subdomain is reasonably designed as a background area. Furthermore, we created monthly wind rose plots at the back trajectory receptor site using only those days in 2018 for which GOSAT observations are available in the BK subdomain (Fig. S4). Since these GOSAT observation days also have consistently westerly winds, we are confident that the background zone is generally upwind of the study regions for other years as well, suggesting that the background area is less affected by the major industrial sources within the study regions.

\subsection{Aircraft data}

The NOAA GGGRN aircraft program collects flask air samples in vertical profiles over North America (Sweeney et al., 2015). The two Canadian sites in the aircraft network are at East Trout Lake (ETL at $54.3501^{\circ} \mathrm{N}$ latitude, $104.9834^{\circ} \mathrm{W}$ longitude, and $492.0 \mathrm{~m}$ asl from October 2005 to December 2018) in Saskatchewan, and Estevan Point (ESP at $49.3825^{\circ} \mathrm{N}$ latitude, $126.5441^{\circ} \mathrm{W}$ longitude and $7.0 \mathrm{~m}$ asl from November 2002 to December 2018) in British Columbia (Fig. 2). The purpose of this program is to detect seasonal and inter-annual changes in trace gas mixing ratios throughout the boundary layer and free troposphere. At the majority of aircraft sites, flights occur every two to three weeks to collect air samples from $500 \mathrm{~m}$ above ground to $8000 \mathrm{~m}$ asl within $\sim 0.1^{\circ}$ of the site location (nearly in situ). After collection, samples are shipped to the NOAA Global Monitoring Laboratory for carefully calibrated and qualitycontrolled measurements. Typical measurement precision of $\mathrm{CH}_{4}$ analysis is $1.2 \mathrm{ppb}$. Detailed descriptions of sampling, measurements, and quality control procedure are described on the network website (NOAA/GML, 2019). Data from the two Canadian sites were obtained from observation package datasets (Cooperative Global Atmospheric Data Integration Project, 2020). There is another station, Dahlen North Dakota (DND at $47.50^{\circ} \mathrm{N}, 99.24^{\circ} \mathrm{W}$, and $472 \mathrm{~m}$ asl from September 2004 to November 2016; Fig. 2) located in the MN subdomain, and data from this site were also analyzed. The DND site was also maintainted by the NOAA/GML (Cooperative Global Atmospheric Data Integration Project, 2020).

\subsection{Satellite data}

We use the latest GOSAT XCH 4 data sets for the period of 2009 to 2019 as produced under a project of the Copernicus Climate Change Services (C3S, https://climate.copernicus.eu) (Buchwitz et al., 2015, 2018, 2019). The Copernicus Climate Data Store (CDS, https://cds.climate.copernicus.eu/) includes several products, and we used one GOSAT data product. The GOSAT $\mathrm{XCH}_{4}$ product is from the University of Leicester (UoL) GOSAT Proxy $\mathrm{XCH}_{4}$ algorithm (v9.0, Parker et al., 2020). Hereafter this data product is referred as GOSAT product. The Proxy algorithm produces $\mathrm{XCH}_{4}$ by computing the ratio of the retrieved $\mathrm{XCH}_{4}$ column and the simultaneously retrieved $\mathrm{XCO}_{2}$ column multiplied by a correction factor for $\mathrm{XCO}_{2}$ variations using a $\mathrm{CO}_{2}$ model, described in detail by Frankenberg et al. $(2005,2006)$. In contrast, the "full physics" (FP) GOSAT $\mathrm{XCH}_{4}$ data product does not require this $\mathrm{CO}_{2}$ correction as $\mathrm{XCH}_{4}$ is retrieved directly (Butz et al., 2011). However, this product was not considered here, because FP data product retrieval requires more complex radiative transfer modeling and a stricter quality filtering process, consequently FP data products are typically much sparser than PR products (Buchwitz et al., 2017). Note that GOSAT is a Sun-synchronous low earth orbit

This article is protected by copyright. All rights reserved. 
satellite launched in January 2009 by the Japanese Space Agency (JAXA), scanning the ground at 1300 local solar time with a footprint diameter of $10.5 \mathrm{~km}$. Each footprint is separated by $\sim 283$ $\mathrm{km}$ along track and $\sim 263 \mathrm{~km}$ across track.

The satellite retrieval validation schemes usually use ground-based $\mathrm{XCH}_{4}$ observations from the Total Carbon Column Observing Network (TCCON) (Wunch et al., 2011, 2015). Buchwitz et al. $(2018,2019)$ discussed the validation results of the $\mathrm{XCH}_{4}$ data products by comparing with the collocated TCCON sites. They reported that all GOSAT products are very stable because they do not show a significant trend in their bias relative to the TCCON observations. Furthermore, Parker et al. (2020) reported the single measurement precision of the latest GOSAT product (v9.0) was $13.72 \mathrm{ppb}$ by comparison to TCCON.

\section{Results and discussion}

\subsection{Satellite data validation}

In the previous section (section 2.3) we discussed the overall GOSAT data quality at the global scale. Here, we also evaluate the GOSAT v9.0 product regionally before using it for trend and source attribution analysis in western Canada because this product was not analyzed previously in this region. In the validation process we compare GOSAT v9.0 product with collocated NOAA/GML aircraft measurements at the ETL site and also with TCCON data at this site.

Since no TCCON sites were available in our study area before 2016 to evaluate the GOSAT data product, we use in-situ vertical profiles from the NOAA/GML aircraft network sites (detailed in section 2.2). We selected the colocation criteria for the GOSAT data evaluation following Wecht et al. (2014). The ETL site domain encompasses $52.9973^{\circ} \mathrm{N}$ to $55.7080^{\circ} \mathrm{N}$ latitude and $107.2914^{\circ} \mathrm{W}$ to $102.6344^{\circ} \mathrm{W}$ longitude, which is roughly $+/-150 \mathrm{~km}$ from the ETL site (latitude: $54.3541^{\circ} \mathrm{N}$ and longitude: $104.9868^{\circ} \mathrm{W}$; Fig. 2). We used 19 flask sample profiles (collocated days) throughout the study period (2009-2019) with each profile corresponding to 1 to 5 satellite observations. Further tightening the domain would exclude more aircraft profiles. Before comparison, aircraft profiles were mapped to the GOSAT pressure grid. Satellite a-priori profiles were used above the aircraft ceiling, and adjusted through application of equation (1) to simulate the GOSAT retrieval from individual satellite observations.

$$
X_{\text {simulate }}=\sum_{l}\left(X_{\text {apri }}^{l}+A K^{l}\left(X_{\text {aircraft }}^{l}-X_{\text {apri }}^{l}\right)\right) W^{l}
$$

Here, $X_{\text {simulate }}$ is the simulated GOSAT retrieval, $l$ is the index of vertical levels, $X_{\text {apri }}$ is the apriori dry air mole fraction of methane, $A K$ is the column averaging kernel, $X_{\text {aircraft }}$ is the aircraft-based flask sampled dry air mole fraction of $\mathrm{CH}_{4}$, and $W$ is the level-dependent pressure weight. All satellite associated variables are available in the satellite data products. We averaged the coincident GOSAT observations to compare with the corresponding simulated aircraft data products. Figure 3(a) suggests that GOSAT data products agree reasonably well with the aircraftbased $\mathrm{XCH}_{4}$ (simulated data products) as expected $\left(\mathrm{R}=0.81, \mathrm{R}^{2}=0.65\right.$ and slope is $1.0 \pm 0.31$; Fig. $3 a)$. $R$ is statistically significant $(\mathrm{p}<0.05)$. Note, the error of the slope is quantified by a bootstrap resampling with replacement technique (Diaconis \& Efron, 1983). During this quantification, we

This article is protected by copyright. All rights reserved. 
first made 100,000 samples of both datasets (aircraft and satellite) by bootstrap random resampling with replacement from the collocated observations of each dataset using 100,000 Monte Carlo runs, then similar to Fig. 3a we obtained 100,000 regression lines and the error of the slope is quantified from the standard deviation of these 100,000 slopes.

Since October 2016, the ETL site also hosts a ground-based TCCON station (Wunch et al., 2018). Therefore, we compared the 2017-2019 GOSAT data at ETL with the collocated TCCON data. Before evaluation, we used spatial $\left( \pm 2^{\circ}\right.$ latitude and $\pm 4^{\circ}$ longitude of the ETL TCCON site) and temporal ( $\pm 2 \mathrm{~h}$ ) criteria to obtain collocated observations. Furthermore, GOSAT data were corrected using the TCCON a priori profile as the common a priori profile, as described by Dils et al. (2014). We obtained a reasonable comparison among all paired observations ( $\mathrm{n}=989)$ with an $\mathrm{R}$ value of $0.61(\mathrm{p}<0.05)$ (Fig. $3 \mathrm{~b})$, which is consistent with previous findings (Dils et al., 2014; Parker et al., 2020). The reasonable agreement between the GOSAT (v9.0) data product and the independently measured high-quality aircraft and TCCON data products allowed us to use the GOSAT v9.0 data product for $\mathrm{CH}_{4}$ trend detection from 2009 to 2019 in western Canada.

We also performed an elevation correction for each GOSAT observation. The elevationcorrected $\mathrm{XCH}_{4}$ is obtained by adding $7 \mathrm{ppb}$ per $1000 \mathrm{~m}$ ground surface elevation increase asl to the original satellite $\mathrm{XCH}_{4}$ observations, as suggested by Buchwitz et al. (2017). The elevation correction that was applied was a single global value, even though the actual elevation correction would depend on latitude (Kort et al., 2014), however the enhancements estimated in this study should not have a bias since we are subtracting from a background domain with a similar latitudinal extent as each source region. Also for the trend analysis in each subdomain, any latitudinal bias would not matter, since it would be the same over time. At locations with high ground surface elevations the total column mixing ratios are more affected by the stratospheric contribution, although mean stratospheric $\mathrm{CH}_{4}$ mixing ratios are lower than tropospheric mixing ratios. Consequently, an elevation correction is required to reduce potential effects associated with location-dependent weighting of tropospheric and stratospheric contributions on total $\mathrm{XCH}_{4}$ (Kort et al., 2014).

\subsection{Trend analysis of satellite $\mathrm{XCH}_{4}$ in subdomains}

In this section we analyze the GOSAT $\mathrm{XCH}_{4}$ data product separately over each subdomain to find trends. We also use aircraft vertical profile measurements at the three NOAA/GML sites to evaluate trends from satellite data.

We started by producing time series using all valid daily GOSAT observations in each subdomain (BK, NE, AB, SK and MN) (Fig. 4). In each panel of Fig. 4 the annual mean (red ' $x$ ' symbol) $\mathrm{XCH}_{4}$ are increasing in all subdomains including $\mathrm{BK}$, which is expected because $\mathrm{CH}_{4}$ has been increasing globally for the last decade (Dlugokencky, 2021; Nisbet et al., 2016). Although annual mean $\mathrm{XCH}_{4}$ is increasing in all subdomains, long term (2009-2019) mean $\mathrm{XCH}_{4}$ (green straight line in each panel of Fig. 4) differs between subdomains. For example, mean $\mathrm{XCH}_{4}$ in SK, $\mathrm{MN}$ and $\mathrm{AB}$ are 1817.2, 1811.7 and $1808.2 \mathrm{ppb}$, respectively, and $\mathrm{XCH}_{4}$ is relatively lower on average in the $\mathrm{BK}$ and $\mathrm{NE}$, but their averages are almost identical ( 1800 ppb). The annual means in each subdomain (red circles in Fig. 5) are higher on average than the annual mean background $\mathrm{XCH}_{4}$ (green circles) except for a few years in NE (2010, 2011, 2014

This article is protected by copyright. All rights reserved. 
and 2015; Fig. 5b). The NE subdomain is spatially close to the BK location, therefore we were very careful for trend analysis in this subdomain . Moreover, the number of observations in each month is also relatively low in this subdomain (Table S1 and S2; further discussion about monthly observations will be provided in the following section), consequently we are unable to capture high $\mathrm{CH}_{4}$ variability due to local emissions (Chan et al., 2020), resulting in lower annual means in those years in the NE subdomain relative to BK. Therefore, we did not consider the NE subdomain for trend analysis, however, we do source attribution analysis using the remaining seven years in the NE. The standard deviation of annual observations in each subdomain ranges from 13-20 ppb (error bars in Fig. 5; Table S1 and S2). The annual standard error of the mean varies from 0.5 to $2.1 \mathrm{ppb}$ among all subdomains. The standard error of the mean remains below $1.0 \mathrm{ppb}$ in the $\mathrm{AB}, \mathrm{SK}$ and MN subdomains for the whole period (Table S1 and S2). The smaller standard errors in these three subdomains are associated primarily with a higher number of observations, because standard deviations are similar in all subdomains, including NE. The consistency in the standard deviation and standard error of the mean in all subdomains suggests our trend analysis in the source subdomains relative to the BK would represent variation primarily due to local emission sources. Near-surface annual mean $\mathrm{CH}_{4}$ (measurements below $1200 \mathrm{~m}$ asl at each site) from three NOAA/GML aircraft measurements have also increased since 2009, with nearly identical annual means of $\mathrm{CH}_{4}$ at DND and ETL sites, however annual mean $\mathrm{CH}_{4}$ at ESP is approximately $30 \mathrm{ppb}$ lower than at the other two sites (Fig. S5a), which is expected because ESP (Fig. 2) is a coastal background site.

Before detecting the trend in each subdomain we evaluated the $\mathrm{XCH}_{4}$ data distribution for the whole period, and we found a near normal distribution in each subdomain (Fig. S6), suggesting the parametric trend estimation approach would be suitable for trend detection. We estimated the long term (2009-2019) trend (ppb/yr) using a linear fit of the annual $\mathrm{XCH}_{4}$ means. Uncertainty of the trend is represented by standard deviation of the slope from a linear fit. Trend in percent change per year $(\% / y r)$ along with uncertainty is also estimated. The trend in $\% / y r$ is obtained by dividing the trend in ppb/yr with the mean $\mathrm{XCH}_{4}$ of the corresponding subdomain and multiplied by 100. Although we are expecting the long-term trends (2009-2019) of the source subdomains would be higher than the background trend, this is not the case in all subdomains. Note we did not perform trend analysis of the NE subdomain. Long term trends (magenta line in each subdomain) at the $\mathrm{AB}, \mathrm{SK}$ and $\mathrm{MN}$ subdomains are $7.0 \pm 0.21,6.92 \pm 0.26$ and $7.03 \pm 0.24 \mathrm{ppb} / \mathrm{yr}$, respectively, while the trend in the BK subdomain is $7.25 \pm 0.30 \mathrm{ppb} / \mathrm{yr}$ (Fig. 4 and 5; see also the Table 1 for trends in \%/yr). All trends are significantly different from zero at a 5\% significance level. Our long-term background trend is similar to the global average $\mathrm{CH}_{4}$ growth rate $(7.29 \pm 0.58 \mathrm{ppb} / \mathrm{yr}$; Fig. S7) over this time period (Dlugokencky et al., 2011), suggesting our background area is well representative of the global background growth rate. We performed the Wilcoxson signed-rank test in all subdomains relative to the BK where the null hypothesis is individual observations (all green dots of each panel in Fig. 4) have equal medians between $\mathrm{BK}$ and source subdomain. The median $\mathrm{XCH}_{4}$ in the $\mathrm{AB}, \mathrm{SK}$ and $\mathrm{MN}$ are statistically different from in the BK. It raises an important question - why are the long term trends in the source subdomains particularly in the $\mathrm{AB}$ and SK lower than the BK trend (Fig. 4 and 5; Table 1) while the mean and median $\mathrm{XCH}_{4}$ levels in the source subdomains are significantly higher than in the BK region? The source subdomains contain a variety of sources that are dominated by oil and gas industries (Fig. 1, 2 and S1) as well as wetlands (Sheng et al., 2018; Fig. S1). However, the background contributes the largest part of $\mathrm{CH}_{4}$ in ambient air (Lan et al., 2019), thus it is difficult to identify the dominant source of $\mathrm{CH}_{4}$ mole fractions above background in the

This article is protected by copyright. All rights reserved. 
ambient air for a particular subdomain. The global $\mathrm{CH}_{4}$ growth rate (Fig. S7) and recent literature (Nisbet et al., 2019) clearly inform us there is a step change (higher growth) in the global $\mathrm{CH}_{4}$ growth rate after 2014. Considering all these facts as well as the BK trend matching the global trend, we hypothesize that source subdomains are affected by short term emission changes from local sources which ultimately lead to lower long term trends than in the background area. We will provide detailed analysis to test this hypothesis in the subsequent section. We also estimate trends in all subdomains for two additional time periods (2009-2013 and 2014-2019) similar as we did for the long-term period (2009-2019). All these trends including long-term trends and global average are shown in Table 1. During the first short period (2009-2013) the BK trend $(5.01 \pm 0.40 \mathrm{ppb} / \mathrm{yr})$ is also close to the global average $(5.09 \pm 0.58$ $\mathrm{ppb} / \mathrm{yr})$, but the BK trend (7.88 \pm 0.59$)$ is lower than the global average $(9.11 \pm 0.58)$ in the second short period (2014-2019). Interestingly, trends in the AB and SK subdomains are higher than the BK trend (not significantly higher) during the first short period, but in the latter period (20142019) these two subdomains ( $\mathrm{AB}$ and SK), including MN, have lower trends than BK (Table 1). We also did a similar trend estimation for the three NOAA/GML aircraft sites using their annual mean $\mathrm{CH}_{4}$ mole fractions near the surface level, resulting in consistent features (Table 1). In this statement we are assuming the DND site is located in the oil and gas industry dominated region, while ESP and ETL sites are representing background locations (Fig. 2). We will provide more discussion on the NOAA/GML aircraft based trends in the following section. All trends listed in Table 1 are significantly different from zero at a 5\% significance level (excluding DND trend in the second short period where $\mathrm{p}>>0.05$ ). The relatively higher trends in all subdomains during the second short period (2014-2019) might be associated with higher global $\mathrm{CH}_{4}$ growth rate after 2013. However, the higher trends in the AB, SK and MN (also DND) subdomains during the first short period indicate that local sources may have some influence on the enhancements above background (details are in the following section). The trends that we estimated using a linear fit of the annual $\mathrm{XCH}_{4}$ means in each subdomain are also evaluated with a bootstrap resampling with replacement technique (Diaconis \& Efron, 1983). For this evaluation, we obtained the mean for each subdomain in each year by bootstrap random resampling with replacement from the observations (the number of samples equals the number of annual observations at each subdomain) using 100,000 Monte Carlo runs. All mean values obtained from the bootstrap resampling technique are almost identical to the means quantified by real observations, suggesting that the mean value in each subdomain is well represented, thus the trend at each subdomain is reasonably quantified.

This article is protected by copyright. All rights reserved. 
Table 1. $\mathrm{XCH}_{4}$ trends (ppb/yr) in all subdomains for three different time periods. Global average $\mathrm{CH}_{4}$ growth rate and $\mathrm{CH}_{4}$ trends of three NOAA/GML aircraft sites are also given. Trends in $\% / y r$ are also given in the parenthesis.

\begin{tabular}{cccc}
\hline Subdomain $^{\mathbf{a}}$ & $\mathbf{2 0 0 9 - 2 0 1 3}$ & $\mathbf{2 0 1 4 - 2 0 1 9}$ & $\mathbf{2 0 0 9 - 2 0 1 9}$ \\
\hline Global average $^{\mathbf{b}}$ & $5.09 \pm 0.58$ & $9.11 \pm 0.58$ & $7.29 \pm 0.58$ \\
BK & $5.01 \pm 0.40$ & $7.88 \pm 0.59$ & $7.25 \pm 0.30$ \\
& $(0.28 \pm 0.02)$ & $(0.43 \pm 0.03)$ & $(0.40 \pm 0.02)$ \\
$\mathrm{AB}$ & $5.78 \pm 0.41$ & $7.72 \pm 0.46$ & $7.0 \pm 0.21$ \\
& $(0.32 \pm 0.02)$ & $(0.42 \pm 0.03)$ & $(0.39 \pm 0.01)$ \\
$\mathrm{SK}$ & $5.88 \pm 0.80$ & $6.55 \pm 0.65$ & $6.92 \pm 0.26$ \\
& $(0.33 \pm 0.04)$ & $(0.36 \pm 0.04)$ & $(0.38 \pm 0.01)$ \\
MN & $5.12 \pm 0.36$ & $6.92 \pm 0.41$ & $7.03 \pm 0.24$ \\
& $(0.29 \pm 0.02)$ & $(0.38 \pm 0.02)$ & $(0.39 \pm 0.01)$ \\
Aircraft & $\mathbf{2 0 0 9 - 2 0 1 3}$ & $\mathbf{2 0 1 4 - 2 0 1 8}$ & $\mathbf{2 0 0 9 - 2 0 1 8}$ \\
ESP & $4.20 \pm 0.55(0.22 \pm 0.03)$ & $7.94 \pm 0.64(0.42 \pm 0.03)$ & $6.83 \pm 0.40(0.36 \pm 0.02)$ \\
ETL & $5.18 \pm 1.89(0.27 \pm 0.10)$ & $9.30 \pm 2.0(0.48 \pm 0.10)$ & $7.60 \pm 0.69(0.40 \pm 0.04)$ \\
DND & $8.69 \pm 0.96(0.46 \pm 0.05)$ & $3.87 \pm 4.04[>>0.05]$ & $8.82 \pm 0.67(0.46 \pm 0.03)$ \\
& & $(0.20 \pm 0.21)[>0.05]$ & \\
\hline
\end{tabular}

${ }^{a}$ We do not quantify $\mathrm{XCH}_{4}$ trends at the NE subdomain (see in the text)

${ }^{\mathrm{b}} \mathrm{Global}$ average $\mathrm{CH}_{4}$ growth rates for three different time periods are quantified by averaging global annual growth rate as illustrated in Fig. S7.

${ }^{\mathrm{c}} \mathrm{CH}_{4}$ trends are estimated at three NOAA/GML aircraft sites from annual mean of surface level measurements (see Fig. S5).

dTime periods for the $\mathrm{CH}_{4}$ trends at the DND site are 2009-2013, 2014-2016 and 2009-2016 (see section 2.2). All trends are statistically significant except the $\mathrm{CH}_{4}$ trend at the DND site during 2014-2016 (p value at square bracket is above 0.05 ).

\subsection{Trend analysis of $\mathrm{XCH}_{4}$ enhancements $\left(\Delta \mathrm{XCH}_{4}\right)$}

In this section we analyze $\mathrm{XCH}_{4}$ enhancements $\left(\Delta \mathrm{XCH}_{4}\right)$ relative to background using the GOSAT data product. Similar to the previous section, we also use aircraft vertical profile measurements at the three NOAA/GML sites to evaluate $\Delta \mathrm{XCH}_{4}$ trends from satellite data.

As we stated in the introduction section, the monthly $\triangle \mathrm{XCH}_{4}$ approach can detect $\mathrm{CH}_{4}$ variability associated with local emission sources, thus $\Delta \mathrm{XCH}_{4}$ analysis for a longer period of time (2009 to 2019) will allow us to improve our previous understanding of $\mathrm{CH}_{4}$ sources in western Canada. Since suitable background selection is also important, we evaluated our background domain (BK, Fig. 2) carefully in the previous sections, confirming that our background region is well representative of $\mathrm{CH}_{4}$ background information. For assessing data availability on a monthly basis at each subdomain including BK, we populated all observations at monthly resolution for each year of the corresponding subdomain in Table S1 and S2. We did not obtain data during November to January in each subdomain, but data were available in all other months of each year in all subdomains with a few exceptions (particularly in the NE subdomain) (Table S1 and S2). The number of monthly observations in the NE subdomain is relatively small which could be associated with smaller domain size and its geographical location (located at higher latitude; Table S1; Fig. 2). Although monthly observations are fewer, we believe the remaining years with positive annual $\triangle \mathrm{XCH}_{4}$ means would capture $\mathrm{CH}_{4}$ variability due to local sources, therefore, we analyze those seven years for source attribution in the NE subdomain. We first quantify monthly mean $\triangle \mathrm{XCH}_{4}$ in each year for all four source subdomains. The annual mean $\triangle \mathrm{XCH}_{4}$ obtained from monthly means are used for trend (not for the NE) and

This article is protected by copyright. All rights reserved. 
source attribution analysis. The annual mean enhancements allowed us to perform source attribution analysis more conveniently because government inventories report their anthropogenic emissions as annual totals. GOSAT-based monthly $\triangle \mathrm{XCH}_{4}$ for each subdomain from 2009-2019 is found by: first quantifying monthly mean background $\mathrm{XCH}_{4}$ each year (using the BK subdomain), and then subtracting the monthly background from each observation, and finally averaging all residuals to represent monthly $\triangle \mathrm{XCH}_{4}$ for each subdomain. Similar to the $\mathrm{XCH}_{4}$, we estimated the $\Delta \mathrm{XCH}_{4}$ trend using a linear fit of the annual mean $\Delta \mathrm{XCH}_{4}$. Uncertainty of the $\Delta \mathrm{XCH}_{4}$ is represented by standard deviation of the slope from linear fits. $\Delta \mathrm{XCH}_{4}$ in percent change per year $(\% / \mathrm{yr})$ along with uncertainty is also estimated similar to the $\mathrm{XCH}_{4}$ trend. The frequency distributions of monthly means $\triangle \mathrm{XCH}_{4}$ in all source subdomains including NE (excluding those four years) are also normally distributed (Fig. S8), suggesting parametric trend analysis would be appropriate for the $\triangle \mathrm{XCH}_{4}$ trends as well.

Figure 6 shows individual $\triangle \mathrm{XCH}_{4}$ along with annual mean $\triangle \mathrm{XCH}_{4}$ relative to the background using the GOSAT data product from 2009-2019. Individual $\Delta \mathrm{XCH}_{4}$ refers to the residual after subtracting the monthly mean $\mathrm{BK} \mathrm{XCH}_{4}$ from individual observations of each subdomain listed in Table S1 and S2. There are positive annual mean $\Delta \mathrm{XCH}_{4}$ (red ' $\mathrm{x}$ ' in each panel) in all subdomains except for four years (2010, 2011, 2014 and 2015) in the NE subdomain (Fig. 6). The mean annual $\triangle \mathrm{XCH}_{4}$ of all source subdomains vary from 2.59 to $7.53,2.98$ to 9.70 , 6.09 to 12.81 , and 5.36 to $10.42 \mathrm{ppb}$, respectively in the NE, AB, SK, and MN (Fig. 6), resulting in large frequencies of positive residuals each year. The lower annual mean $\mathrm{XCH}_{4}$ relative to the $\mathrm{BK}$ in those four years in NE (Fig. 5b) result in negative annual mean $\Delta \mathrm{XCH}_{4}$, therefore, $\Delta \mathrm{XCH}_{4}$ trend analysis was not performed in the NE subdomain. For the other three subdomains we are estimated long term (2009-2019) $\Delta \mathrm{XCH}_{4}$ trends, but did not find any statistically significant trends (Table 2), so long term trends are not illustrated in each panel of Fig. 6. However, if we look at each panel (except NE) carefully, $\Delta \mathrm{XCH}_{4}$ is increasing from 2009 to 2013 particularly in the $\mathrm{AB}$ and SK subdomains. Similar to $\mathrm{XCH}_{4}$ trends we also estimated trends in three subdomains (AB, SK and MN) for two additional time periods (2009-2013 and 2014-2019). We found marginally statistically significant (significantly different from zero at a $5 \%$ significance level) increasing $\triangle \mathrm{XCH}_{4}$ trends in the $\mathrm{AB}(1.39 \pm 0.47 \mathrm{ppb} / \mathrm{yr} ; 20.44 \pm 6.91 \% / \mathrm{yr}, \mathrm{p}=0.06)$ and SK (1.09 $\pm 0.46 \mathrm{ppb} / \mathrm{yr} ; 10.42 \pm 4.40 \% / \mathrm{yr}, \mathrm{p}=0.09)$ subdomains during the first short period (20092013) (Table 2). $\triangle \mathrm{XCH}_{4}$ trend in the $\mathrm{MN}$ subdomain is not statistically significant (Table 2). In the latter period (2014-2019) trends are negative (Table 2), although annual mean $\Delta \mathrm{XCH}_{4}$ are positive. While analysing $\mathrm{XCH}_{4}$ trends we found $\mathrm{XCH}_{4}$ trends in the $\mathrm{AB}, \mathrm{SK}$ and $\mathrm{MN}$ subdomains are higher than BK trends during the first short period, but lower in the latter short period (Table 1). We hypothesized that these patterns are associated with local emission changes and also with global background patterns. But $\triangle \mathrm{XCH}_{4}$ trends during these two periods have relatively less association with global growth rate because higher background growth rates are affecting all subdomains, including BK, similarly during the second short period (Table 1). Therefore, even though we found positive annual mean $\Delta \mathrm{XCH}_{4}$, local sources might have lower emissions, particularly in the AB and SK subdomains, during the latter period (2014-2019), resulting in negative trends, although they are not statistically significant (Table 2). We further evaluated this statement by analysing both $\mathrm{CH}_{4}$ and $\Delta \mathrm{CH}_{4}$ trends using $\mathrm{CH}_{4}$ measurements at three aircraft sites (Table 1 and 2; Fig. S5). $\mathrm{CH}_{4}$ and $\Delta \mathrm{CH}_{4}$ trends are estimated following similar methods as we applied for estimating satellite based trends. $\mathrm{CH}_{4}$ observations up to $1200 \mathrm{~m}$ asl for ETL (2009-2018) and DND (2009-2016), and up to $800 \mathrm{~m}$ asl for ESP (2009-2018) were considered to quantify surface level annual mean of a given year. Enhancement (or vertical

This article is protected by copyright. All rights reserved. 
gradient, $\Delta \mathrm{CH}_{4}$ ) is quantified for each month at all stations by subtracting monthly mean $\mathrm{CH}_{4}$ in layers between 3500 to $5500 \mathrm{~m}$ asl from monthly mean $\mathrm{CH}_{4}$ up to $2500 \mathrm{~m}$ asl, following Lan et al. (2019). Similar to the satellite based $\Delta \mathrm{XCH}_{4}$, we quantified annual mean aircraft based $\Delta \mathrm{CH}_{4}$ by averaging monthly mean $\Delta \mathrm{CH}_{4} . \mathrm{CH}_{4}$ trends at the ETL site during both shorter periods are higher than global averages (Table 1), therefore, we might get $\Delta \mathrm{CH}_{4}$ trend at the ELT site as well. We found a marginally statistically significant $\Delta \mathrm{CH}_{4}$ trend $(1.74 \pm 0.58 \mathrm{ppb} / \mathrm{yr}$;

8.94 $\pm 2.98 \% / y r ; p=0.06$; Table 2) at the ETL site during the second short period but we did not find a significant trend at SK. Although the ETL site is at the northern edge of the SK subdomain, it is located at the outside of oil and gas dominated area (Fig. 2). We therefore created a small subdomain $\left(53.00^{\circ} \mathrm{N}\right.$ to $56.7^{\circ} \mathrm{N}$ and $110.00^{\circ} \mathrm{W}$ to $\left.98.00^{\circ} \mathrm{W}\right)$ at the center of the ETL site for evaluating $\triangle \mathrm{CH}_{4}$ trends at the ETL site with the GOSAT data. We found a consistent $\triangle \mathrm{XCH}_{4}$ trend $(1.27 \pm 0.03 \mathrm{ppb} / \mathrm{yr} ; \mathrm{p}<0.05)$ at the ETL site if we consider $\triangle \mathrm{XCH}_{4}$ from 2014 to 2017. This analysis suggests that the ETL site and SK subdomain are affected by local emissions sources differently. $\Delta \mathrm{XCH}_{4}$ trends at the $\mathrm{MN}$ site and DND $\left(\Delta \mathrm{CH}_{4}\right)$ subdomain are statistically insignificant for both time periods (Table 2). Note that the DND site and MN subdomain are collocated (Fig. 2), and Lan et al. (2019) reported that the DND site is heavily influenced by emissions from oil and gas activities from the surrounding area. Lan et al. (2019) found a decreasing $\triangle \mathrm{CH}_{4}$ trend at the ETL site and increasing trend at the DND site for 20062015, we verify these findings with the latest NOAA/GML data product (Cooperative Global Atmospheric Data Integration Project, 2020) but using our trend estimation method. We found consistent findings as reported in the Lan et al. (2019), which gave us confidence in our calculations. Moreover, since we obtained a general agreement between satellite and aircraft based trends our initial thought about trends between these two products (see section 1) are validated. Finally, the GOSAT $\triangle \mathrm{XCH}_{4}$ trends were evaluated by estimating mean $\triangle \mathrm{XCH}_{4}$ in each subdomain using a bootstrap resampling with replacement technique (Diaconis \& Efron, 1983), as we did previously for the $\mathrm{XCH}_{4}$ trends. The bootstrap $\Delta \mathrm{XCH}_{4}$ means are almost identical to the sample means, so the $\Delta \mathrm{XCH}_{4}$ trend at each subdomain is reasonably quantified.

Table 2. $\triangle \mathrm{XCH}_{4}$ trends (ppb/yr) in all subdomains (not $\mathrm{NE}$ ) for three different time periods. $\Delta \mathrm{CH}_{4}$ trends of three NOAA/GML aircraft sites are also given. Trends in the parenthesis are referring to \%/yr. P value is given in a square bracket to assess the trend's statistical significance at $5 \%$ significance level.

\begin{tabular}{cccc}
\hline Subdomain $^{\mathbf{a}}$ & $\mathbf{2 0 0 9 - 2 0 1 3}$ & $\mathbf{2 0 1 4 - 2 0 1 9}$ & $\mathbf{2 0 0 9 - 2 0 1 9}$ \\
\hline $\mathrm{AB}$ & $1.39 \pm 0.47[0.06]^{\mathrm{a}}$ & $-0.06 \pm 0.51$ & $-0.03 \pm 0.22$ \\
& $(20.44 \pm 6.91)[0.06]$ & $(-1.05 \pm 8.96)$ & $(-0.48 \pm 3.15)$ \\
$\mathrm{SK}$ & $1.09 \pm 0.46[0.09]$ & $-0.62 \pm 0.51$ & $-0.16 \pm 0.21$ \\
& $(10.42 \pm 4.40)[0.09]$ & $(-6.70 \pm 5.51)$ & $(-1.63 \pm 2.14)$ \\
$\mathrm{MN}$ & $0.69 \pm 0.56$ & $-0.30 \pm 0.54$ & $-0.01 \pm 0.19$ \\
& $(8.67 \pm 7.04)$ & $(-3.85 \pm 6.93)$ & $(-0.13 \pm 2.41)$ \\
Aircraft & $\mathbf{2 0 0 9 - 2 0 1 3}$ & $\mathbf{2 0 1 4 - 2 0 1 8}$ & $\mathbf{2 0 0 9 - 2 0 1 8}$ \\
ESP & $-1.01 \pm 1.56$ & $-0.35 \pm 0.28$ & $-0.30 \pm 0.35$ \\
& $(-10.85 \pm 16.76)$ & $(-4.17 \pm 3.34)$ & $(-3.39 \pm 3.95)$ \\
ETL & $0.03 \pm 1.05$ & $1.74 \pm 0.58[0.06]$ & $0.01 \pm 0.34$ \\
& $(0.14 \pm 5.05)$ & $(8.94 \pm 2.98)[0.06]$ & $(0.05 \pm 1.69)$ \\
DND & $-0.24 \pm 0.96$ & $-2.55 \pm 1.99$ & $0.40 \pm 0.50$ \\
& $(-0.77 \pm 3.08)$ & $(-7.41 \pm 5.78)$ & $(1.24 \pm 1.54)$ \\
\hline
\end{tabular}

${ }^{a}$ We do not quantify $\triangle \mathrm{XCH}_{4}$ trends at the $\mathrm{NE}$ subdomain (see in the text)

${ }^{b}$ Trends with $\mathrm{P}$ value of up to 0.09 are defined as marginally statistically significant and $\mathrm{P}$ value is given in the square bracket. Trends without square bracket indicates statistically insignificant $(\mathrm{p}>>0.05)$

This article is protected by copyright. All rights reserved. 


\subsection{Source attribution analysis}

While analysing $\triangle \mathrm{XCH}_{4}$ trends we found stronger trends for shorter time periods. For instance, we obtained marginally statistically significant $\triangle \mathrm{XCH}_{4}$ trends in the $\mathrm{AB}$ and $\mathrm{SK}$ subdomains during the period of 2009-2013, however no trend isappears for the longer time period (2009-2019). We hypothesized local emission sources are strongly influencing the $\triangle \mathrm{XCH}_{4}$ above background and subsequently control the $\Delta \mathrm{XCH}_{4}$ trends. To justify this statement we investigated the influence of all major sources on the annual $\Delta \mathrm{XCH}_{4}$ in each subdomain for three different time periods (2009-2013; 2014-2019 and 2009-2019) using both a correlation analysis as well as a stepwise multivariate linear regression analysis. In the correlation analysis we simply quantify the correlation coefficient (R) between annual mean $\Delta \mathrm{XCH}_{4}$ and annual mean source specific emissions for the corresponding time and location. In the correlation analysis we investigated relations with six source categories which are wetland, agriculture, waste, fugitive, energy production and new wells. We provided basic information about these categories in the introduction section and several figures (Fig. 1, Fig. S1 and Fig. S2). Although all these categories except the wetland emissions (gridded data) represent provincial totals, our comparison of subdomain scale $\Delta \mathrm{XCH}_{4}$ with provincial total inventories is a reasonable choice, because the AB subdomain covers all Alberta, SK contains the major urban areas of Saskatchewan and most of the oil and gas wells, NE also represents all oil and gas wells in British Columbia (Fig. 2). But, we should be careful about NE because this small subdomain might also be responsible for a portion of provincial total emissions particularly from the agriculture and waste sectors. It is important to note that emissions of all these sources (anthropogenic and natural) have uncertainties, and since our major goal is $\mathrm{CH}_{4}$ trend and source attribution analysis using satellite data, quantifying uncertainties in the emission levels are beyond our focus. But readers are referred to previous studies (Bloom et al., 2017; CAPP, 2019a; Chan et al., 2020) and government reports (NIR, 2020) for a discussion of uncertainties in emission inventories. Before analysing correlation with these inventories, we also compared annual fugitive emissions with annual total oil and gas production (Fig. S9) and new well counts (Fig. S10) to see whether fugitive emissions are coming from the oil and gas production or development phases. The figures suggest the fluctuating patterns of fugitive emissions are better explained by new well counts in each province (Fig. S10) compared with total production patterns (Fig. S9). Since the main focus of this study is not quantifying fugitive emissions from Canada's oil and gas supply chain, further study is recommended, similar to Alvarez et al. (2018). We also assumed new annual oil and gas well counts represent oil and gas development activities and therefore new well counts have been considered to evaluate the relationship with $\Delta \mathrm{XCH}_{4}$ variation as well. The total annual new oil and gas well counts (also known as "total completions" in a given year) include all types of new well drilling that were classified by the Canadian Committee on Statistics of Drilling (CAPP, 2019a). While performing comparisons we did some adjustments in the time period (see footnotes of Table 3).

In the case of statistically significant $\Delta \mathrm{XCH}_{4}$ trends for the period 2009-2013 at the $\mathrm{AB}$ subdomain, all major sources, except the agriculture sector, have strong positive correlation with annual mean $\Delta \mathrm{XCH}_{4}$ (Table 3). This indicates emissions of all these sources have impact on the positive $\triangle \mathrm{XCH}_{4}$ trend during this shorter period. However, wetland contribution seem more important as the ' $R$ ' value $(0.86)$ is marginally statistically significant $(p=0.06)$. We do not find any strong evidence for source attribution of the $\Delta \mathrm{XCH}_{4}$ trend of the second shorter period (2014-2019). However we found wetland emissions and annual mean $\Delta \mathrm{XCH}_{4}$ are decreasing

This article is protected by copyright. All rights reserved. 
particularly during the first two years of this period, indicating wetland emissions remain the major driving factor to control the $\triangle \mathrm{XCH}_{4}$ in the $\mathrm{AB}$ subdomain for all time periods as evident with the $\mathrm{R}$ value during 2009-2015 ( $\mathrm{R}=0.86$; $\mathrm{p}=0.01$; see Table 3 footnotes). We found the oil and gas sector is clearly dominating the $\Delta \mathrm{XCH}_{4}$ trends in the $\mathrm{SK}$ subdomain for all periods (Table 3). The relation in the second short period is important in the emissions reduction perspective, because the strong correlation of the $\Delta \mathrm{XCH}_{4}$ during this declining period (Table 2) with the oil and gas sector and also the agriculture suggesting emissions reduction from anthropogenic sources would make a difference in the atmospheric $\mathrm{CH}_{4}$. Note the $\triangle \mathrm{XCH}_{4}$ trend of the second short period is not statistically significant in SK, which might be due to interannual fluctuation of $\Delta \mathrm{XCH}_{4}$. The interannual fluctuation of $\Delta \mathrm{XCH}_{4}$ is in general agreement with new well count variations during this period (Fig. S2), also indicating the oil and gas sector has an impact on the $\Delta \mathrm{XCH}_{4}$. Furthermore, the interannual fluctuation of $\Delta \mathrm{XCH}_{4}$ particularly during the 2014-2017 period (Fig. 6b and 6c) are nearly identical to the emissions pattern reported in the Chan et al. (2020) study (red bars in Fig 4 of their study). It should be noted that the declining oil and gas activities in this jurisdiction including Alberta and British Columbia during the period of 2014-2016 might be associated with less capital investment due to economic shifts in the relative profitability of marketable natural gas and other hydrocarbons (CAPP, 2019b; Lan et al., 2019). Source attribution analysis in the MN subdomain indicates oil and gas sector is the major driver for all periods as well (Table 3), although we do not find a statistically significant trend in this subdomain (Table 2). As mentioned earlier, we discarded four years of $\Delta \mathrm{XCH}_{4}(2010,2011$, 2014 and 2015) from the NE subdomains, so trend analysis was not performed, but we did source attribution analysis using the remaining seven years $\triangle \mathrm{XCH}_{4}$ data. We obtained strong association with both wetland and oil and gas sectors, but the association with the oil and gas sector is marginally statistically significant (Table 3), suggesting the oil and gas sector is the major driver of the annual $\triangle \mathrm{XCH}_{4}$ above background in the $\mathrm{NE}$ subdomain.

In addition to the correlation analysis, a stepwise multivariate linear regression analysis was performed to see how variables or combinations of variables explained the annual enhancement $\left(\mathrm{XCH}_{4}\right)$ trends in the $\mathrm{AB}$ and $\mathrm{SK}$ subdomains. Multivariate models considered were based on all combinations of up to three variables - using more than this overfit the regression models given the limited number of annual data points. A "best" multivariate model was chosen based on a p-value criterion when adding and removing variables. Annual values for six explanatory variables were considered: energy production, new well counts, fugitive emissions, agricultural emissions, waste emissions, and wetland emissions. We only considered regression models with positive coefficients since each of the explanatory variables are a type of emission or related to emissions and should contribute to change in annual $\Delta \mathrm{XCH}_{4}$. Therefore, we reasoned that regression models with negative coefficients did not make physical sense and decided to exclude them. The analysis considered the two short periods (2009-2013, 2014-2019) as well as the full period (2009-2019) [the actually analysis period of the second and full periods was up to 2018, see footnotes of Table 3]. In the AB subdomain, a statistically significant $(\mathrm{p}<0.1)$ model was only found for the first short period (2009-2013). In this period, a regression model with wetland emissions $\left(\mathrm{R}^{2}=0.74, \mathrm{p}=0.06\right)$ was the best overall model in the stepwise regression based on coefficient $\mathrm{p}$-value selection criterion. None of the two or three variable models with positive coefficients were statistically significant. The best two variable model was with wetland emissions and energy production $\left(\mathrm{R}^{2}=0.82, \mathrm{p}=0.18\right)$, while the best three variable model had wetland emissions, new well counts, and fugitive emissions $\left(\mathrm{R}^{2}=0.77, \mathrm{p}=0.59\right)$. Although wetland emissions are likely to be the major driver for controlling $\triangle \mathrm{XCH}_{4}$ trends in the

This article is protected by copyright. All rights reserved. 
Alberta region (as found in both the correlation and stepwise multivariate linear regression analysis), we cannot ignore the influence of emissions from the oil and gas sector in this region because ' $R$ ' is positive in all periods, particularly with the new wells variable (Table 3 ). Recall that we were unable to quantity $\triangle \mathrm{XCH}_{4}$ for three winter months (January, November and December) each year in all subdomains due to lack of $\mathrm{XCH}_{4}$ observations during these months. So wetland emissions might obscure oil and gas associated emissions a bit in AB, particularly during warmer months (Chan et al., 2020). In the SK subdomain, statistically significant models were found for all three periods which we also obtained in the correlation analysis. In the first short period (2009-2013) the best single variable regression model was with energy production $\left(\mathrm{R}^{2}=0.87, \mathrm{p}=0.02\right)$ which was also chosen as the best overall model in the stepwise regression based on coefficient $\mathrm{p}$-value selection criterion. The best two variable model had energy production and wetland emissions $\left(\mathrm{R}^{2}=0.95, \mathrm{p}=0.05\right)$. The best three variable model with positive coefficients had energy production, wetland emissions and new well counts $\left(\mathrm{R}^{2}=0.98\right.$, $\mathrm{p}=0.20$ ) but was not statistically significant. In the second short period (2014-2019) the best single variable model was with fugitive emissions $\left(\mathrm{R}^{2}=0.43, \mathrm{p}=0.23\right)$ but was not statistically significant. The best overall model based on coefficient $\mathrm{p}$-value selection, was a two-variable model with fugitive emissions and agriculture $\left(\mathrm{R}^{2}=0.92, \mathrm{p}=0.07\right)$. There were no three variable models with all positive coefficients. In the full period (2009-2019) the best single variable model was with new well counts $\left(\mathrm{R}^{2}=0.31, \mathrm{p}=0.09\right)$ which was also the best overall model in the stepwise regression based on coefficient p-value selection. The best two and three variable models with positive coefficients were not statistically significant. The two variable model had new well counts and energy production $\left(\mathrm{R}^{2}=0.38, \mathrm{p}=0.19\right)$ while the best three variable model added agriculture $\left(\mathrm{R}^{2}=0.45, \mathrm{p}=0.28\right)$. Among the six variables examined only waste emissions were not included in at least one statistically significant model.

Overall it is evident major findings with both multivariate linear regression and univariate correlation analysis are almost identical, suggesting that both wetland and oil and gas sectors are controlling the $\mathrm{CH}_{4}$ growth rate in the western Canada, but the oil and gas sector has a relatively large impact for the $\mathrm{CH}_{4}$ above background in Northeast BC and Saskatchewan. However, if we reasonably consider wetland emissions might obscure oil and gas associated emission during warmer months, and winter months have no sufficient GOSAT $\mathrm{XCH}_{4}$ observations (January, November and December of each year) to capture oil and gas associated emissions, we would claim that oil and gas sector is the dominant driver of $\mathrm{CH}_{4}$ growth in the AB subdomain as well. So if we consider the oil and gas sector is also adominant factor in $\mathrm{AB}$, then we find the average combined growth rate of Alberta and Saskatchewan together between 2009-2013 is $15.43 \pm 8.19 \% / \mathrm{yr}$ (found by averaging the $\mathrm{AB}$ and $\mathrm{SK}$ growth rates; uncertainty is quantified by propagating their errors, Table 2). We also estimated oil and gas emissions growth rate of $\sim 8.0 \% / y r$ between 2009-2013 in Alberta and Saskatchewan from the annual emissions in a recent study (Chan et al., 2020; see red bars in Fig. 4 of their study; emissions of 2009 was assumed to be $60 \%$ higher than government inventory; NIR, 2020); this estimated growth rate is within the uncertainty range of our average growth rate $(15.43 \pm 8.19 \% / \mathrm{yr})$. Therefore, we posit that our estimated growth rate (15.43 $\pm 8.19 \% / y r)$ between 2009-2013 in Alberta and Saskatchewan would be consistent with the oil and gas emissions trend in this region for the same period. As we found that satellite based $\triangle \mathrm{XCH}_{4}$ can attribute $\mathrm{CH}_{4}$ sources consistently, policy relevant (ECCC, 2017) $\mathrm{CH}_{4}$ emission reduction impacts could be detected if we perform time series analysis of satellite observations such as GOSAT proxy $\mathrm{XCH}_{4}$ product (v9.0) over a longer period of time. So,

This article is protected by copyright. All rights reserved. 
further study is recommended to determine whether the fluctuation of $\Delta \mathrm{XCH}_{4}$ after 2014 is associated with policy intervention.

In this study we attempted meet our objectives, despite limited data. Deriving annual mean enhancements $\left(\triangle \mathrm{XCH}_{4}\right)$ without data from the three winter months $\left(\mathrm{XCH}_{4}\right.$ data is not available from November to January of each year in all subdomains) for trend and source attribution analysis may lead to error because $\mathrm{CH}_{4}$ emissions have high seasonality. With the multivariate linear regression and univariant correlation analysis we reasonably claim that oil and gas sector is the dominant driver of $\mathrm{CH}_{4}$ growth in western Canada, although wetland emissions are also important. However, future study with monthly emission data for each category and year-round consistent frequency of $\mathrm{XCH}_{4}$ observations from recent satellite missions will allow more certain quantification of the contribution of each source category in the detected trends.

Table 3. Relation between annual mean $\triangle \mathrm{XCH}_{4}$ and major emission sources.

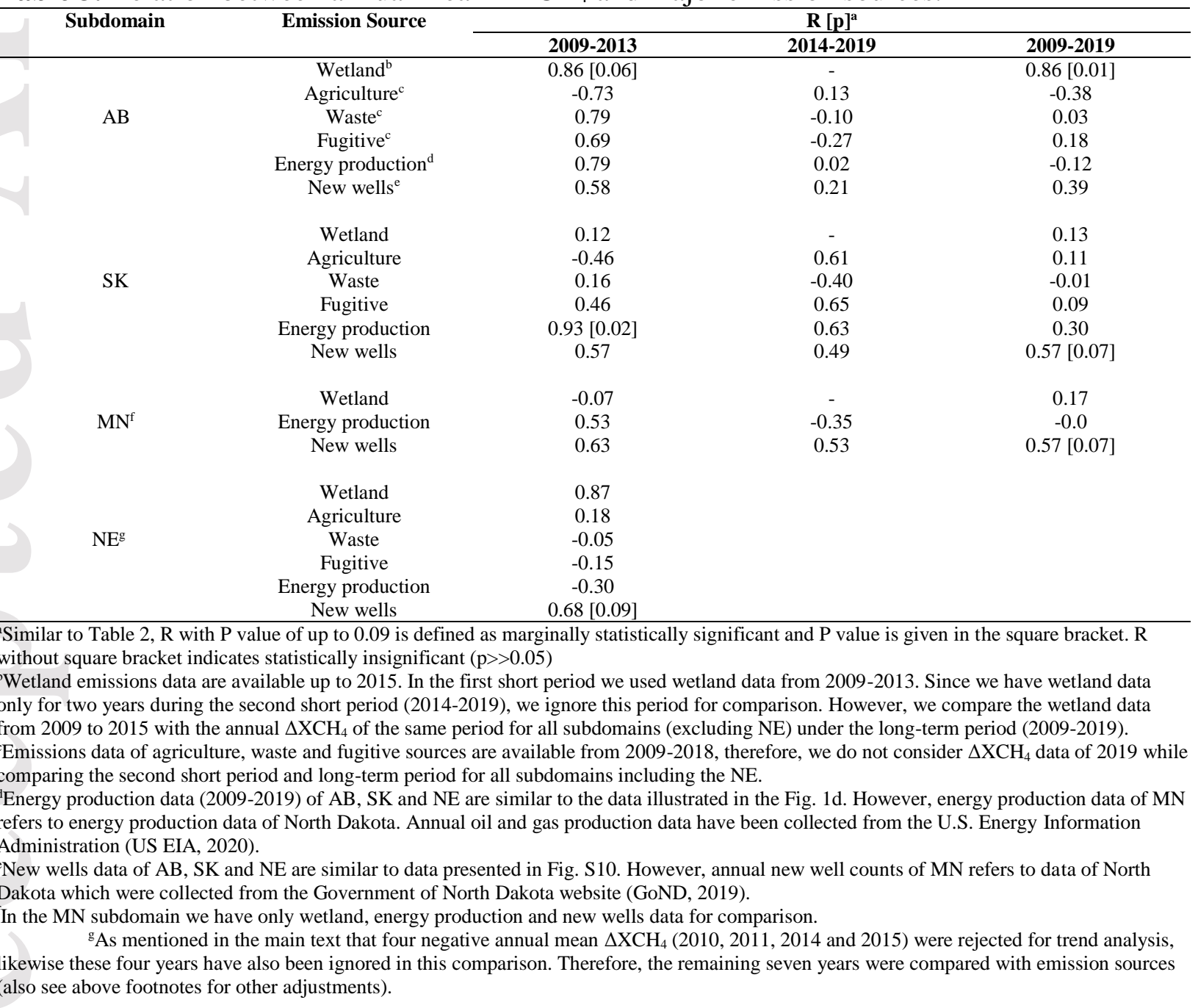

\section{Summary and conclusions}

In this study the latest GOSAT proxy (v9.0) data product of column-averaged dry-air mole fraction of atmospheric methane $\left(\mathrm{XCH}_{4}\right)$ were analyzed for the period 2009-2019 to detect

This article is protected by copyright. All rights reserved. 
$\mathrm{CH}_{4}$ trends in the three western Canadian provinces. We compared our estimated trends $\left(\mathrm{XCH}_{4}\right)$ against the global $\mathrm{CH}_{4}$ growth rate. Furthermore, we quantified $\mathrm{CH}_{4}$ enhancements $(\triangle \mathrm{XCH})_{4}$ after removing appropriate background levels, and attempted to estimate $\Delta \mathrm{XCH}_{4}$ trends in several western Canadian subdomains. We also evaluated our $\triangle \mathrm{XCH}_{4}$ trends by comparing them with $\left(\Delta \mathrm{CH}_{4}\right)$ trends determined from NOAA/GML aircraft in-situ profiles. Finally, we performed source attribution analysis to identify the dominant sources contributing to the detected trends.

Before performing the trend and source attribution analysis, we evaluated the $\mathrm{XCH}_{4}$ data product with the collocated aircraft in-situ measurements and TCCON column measurements, which resulted in a consistent comparison. We found increasing trends in all subdomains from 2009-2019 using GOSAT $\mathrm{XCH}_{4}$ data. These trends are statistically significant but not higher than the background trend $(7.25 \pm 0.30 \mathrm{ppb} / \mathrm{yr})$ during this long-term period (2009-2019), suggesting that local to regional sources influenced the trends in all subdomains. The background trend was consistent with the global growth rate $(7.29 \pm 0.58 \mathrm{ppb} / \mathrm{yr})$ from remote surface in-situ observations suggesting that the background domain was appropriate. However, if we consider trend estimation for shorter periods, we found some interesting features particularly in the Alberta and Saskatchewan subdomains. The trends during 2009-2013 in these two subdomains (AB: $5.78 \pm 0.41 ; \mathrm{SK}: 5.88 \pm 0.80 \mathrm{ppb} / \mathrm{yr}$ ) are higher (not significantly) than background trend $(5.01 \pm 0.40 \mathrm{ppb} / \mathrm{yr})$, but trends are smaller (AB: 7.72 \pm 0.46 ; SK: $6.55 \pm 0.65 \mathrm{ppb} / \mathrm{yr})$ than background trend (7.88 $\pm 0.59 \mathrm{ppb} / \mathrm{yr})$ after 2013 (2014-2019). Similarly we analyzed $\Delta \mathrm{XCH}_{4}$ trends for three time periods, resulting with a marginally statistically significant positive $\Delta \mathrm{XCH}_{4}$ trends in the AB (1.39 $\pm 0.47 \mathrm{ppb} / \mathrm{yr})$ and SK (1.09 $\pm 0.46 \mathrm{ppb} / \mathrm{yr})$ subdomains during 2009-2013, but did not find any detectable trends if we consider either long-term (2009-2019) or the second shorter period (2014-2019), suggesting again local sources might have strong influences in these two regions. In the NE subdomain we were unable to perform trend analysis because four years were identified with negative annual mean $\Delta \mathrm{XCH}_{4}$, which we believe was due to fewer observations in the NE subdomain. We also hypothesized the statistically insignificant trends in the $\mathrm{AB}$ and $\mathrm{SK}$ subdomains during 2014-2019 result from fluctuating annual means of $\Delta \mathrm{XCH}_{4}$ in these two areas. These results, including the features of the first short period, are consistent with other studies. We also found satellite based trends are comparable with the NOAA/GML aircraft based trends.

In our source attribution analysis, we compare annual mean $\triangle \mathrm{XCH}_{4}$ with emissions from all known major sources (wetland, agriculture, waste, fugitive emissions from oil and gas), and energy production and annual oil and gas new well counts (representing oil and gas development activities) for three time periods. We also performed source attribution analysis in the NE subdomain using the remaining seven years of positive annual mean $\Delta \mathrm{XCH}_{4}$. In general we found both wetland and oil and gas sectors are controlling the $\mathrm{CH}_{4}$ growth rate in western Canada, interpreting that the oil and gas sector has a relatively large impact on the $\mathrm{CH}_{4}$ above background in western Canada. Furthermore, we found the average $\mathrm{CH}_{4}$ growth rate in Alberta and Saskatchewan is $15.43 \pm 8.19 \% / y r$ between $2009-2013$ and is consistent with the oil and gas emissions trend during the same period. Finally, although there are limited satellite observations particularly in the winter months, we are able to demonstrate GOSAT $\mathrm{XCH}_{4}$ data product can still attribute $\mathrm{CH}_{4}$ sources consistently, and therefore policy relevant $\mathrm{CH}_{4}$ emissions reduction

This article is protected by copyright. All rights reserved. 
features from anthropogenic sources such as oil and gas industries in Canada could be detected in future if we analyzed satellite observations with adequate care.

\section{Acknowledgments and Data}

The authors would like to express appreciation to the Pacific Institute for Climate Solutions (https://pics.uvic.ca/) to support Graduate Fellowship to SMNI. PLJ is funded by the NSERC Discovery Grant Program. We also would like to acknowledge Copernicus Climate Change Service (C3S) (http://climate.copernicus.eu/) for making the satellite data publicly available. CF and IA are funded by European Space Agency (ESA). RJP and HB are funded via the UK National Centre for Earth Observation (NCEO grant numbers: NE/R016518/1 and NE/N018079/1). We acknowledge funding from the ESA GHG-CCI and Copernicus C3S projects. We thank the Japanese Aerospace Exploration Agency, National Institute for Environmental Studies, and the Ministry of Environment for the GOSAT data and their continuous support as part of the Joint Research Agreement. This research used the ALICE High Performance Computing Facility at the University of Leicester for the GOSAT retrievals.

TCCON data from the ETL site were obtained from the TCCON archive (https://tccondata.org). Funding for the ETL TCCON station is provided by CFI/ORF, NSERC, and the CSA. The NOAA Global Monitoring Laboratory (GML) is highly appreciated for methane mole fraction data from their aircraft measurements, and these data are publicly available (http://dx.doi.org/10.25925/20190108). We would like to offer special thanks to Kirk Thoning of NOAA/GML for producing 2018 back trajectories. We also acknowledge several governments for accessing oil and gas development activities data and emission inventories from their public domains. Those valuable data were very helpful to interpret our satellite-based findings.

All datasets used in this research work are publicly available and can be accessed through web portals and references we have provided in the manuscript.

\section{References}

AER ST37 (Alberta Energy Regulator). (2019). ST37: List of Wells in Alberta Monthly Updates. Surface Holes Shapefile. Retrieved August 16, 2019, from https://www.aer.ca/providinginformation/data-and-reports/statistical-reports/st37

Alvarez, R. A., Zavala-Araiza, D., Lyon, D. R., Allen, D. T., Barkley, Z. R., Brandt, A. R., et al. (2018). Assessment of methane emissions from the U.S. oil and gas supply chain. Science, 361(6398), 186 LP - 188. https://doi.org/10.1126/science.aar7204

BC OGC (British Columbia Oil and Gas Commission). (2019). Online Services: Geospatial Services, Wells and Facility. Well Surface Hole Locations (Permitted). Retrieved August 5, 2019, from https://data-bcogc.opendata.arcgis.com/

Bergamaschi, P., Houweling, S., Segers, A., Krol, M., Frankenberg, C., Scheepmaker, R. A., et al. (2013). Atmospheric CH4 in the first decade of the 21st century: Inverse modeling analysis using SCIAMACHY satellite retrievals and NOAA surface measurements. Journal of Geophysical Research: Atmospheres, 118(13), 7350-7369. https://doi.org/10.1002/jgrd.50480

This article is protected by copyright. All rights reserved. 
Bloom, A. A., Bowman, K. W., Lee, M., Turner, A. J., Schroeder, R., Worden, J. R., et al. (2017). A global wetland methane emissions and uncertainty dataset for atmospheric chemical transport models (WetCHARTs version 1.0). Geosci. Model Dev., 10(6), 21412156. https://doi.org/10.5194/gmd-10-2141-2017

Bruhwiler, L. M., Basu, S., Bergamaschi, P., Bousquet, P., Dlugokencky, E., Houweling, S., et al. (2017). U.S. CH4 emissions from oil and gas production: Have recent large increases been detected? Journal of Geophysical Research: Atmospheres, 122(7), 4070-4083. https://doi.org/10.1002/2016JD026157

Buchwitz, M., Reuter, M., Schneising, O., Boesch, H., Guerlet, S., Dils, B., et al. (2015). The Greenhouse Gas Climate Change Initiative (GHG-CCI): Comparison and quality assessment of near-surface-sensitive satellite-derived $\mathrm{CO} 2$ and $\mathrm{CH} 4$ global data sets. Remote Sensing of Environment, 162, 344-362. https://doi.org/https://doi.org/10.1016/j.rse.2013.04.024

Buchwitz, M., Schneising, O., Reuter, M., Heymann, J., Krautwurst, S., Bovensmann, H., et al. (2017). Satellite-derived methane hotspot emission estimates using a fast data-driven method. Atmospheric Chemistry and Physics, 17(9), 5751-5774. https://doi.org/10.5194/acp-17-5751-2017

Buchwitz, M., Reuter, M., Schneising, O., Bovensmann, H., Burrows, J. P., Boesch, H., et al. (2018). Copernicus Climate Change Service (C3S) Global Satellite Observations of Atmospheric Carbon Dioxide and Methane. Advances in Astronautics Science and Technology, 1(1), 57-60. https://doi.org/10.1007/s42423-018-0004-6

Buchwitz, M., Reuter, M., Schneising-Weigel, O., Aben, I., Wu, L., Hasekamp, O. P., et al. (2019). Product User Guide and Specification ( PUGS ) - Main document for Greenhouse Gas ( GHG : CO 2 \& CH 4 ) data set CDR 3 ( 2003-2018) C3S_312b_Lot2_DLR Atmosphere. Retrieved August 20, 2020, from http://wdc.dlr.de/C3S_312b_Lot2/Documentation/GHG/PUGS/C3S_D312b_Lot2.3.2.3v1.0_PUGS-GHG_MAIN_v3.1.pdf

Butz, A., Guerlet, S., Hasekamp, O., Schepers, D., Galli, A., Aben, I., et al. (2011). Toward accurate CO2 and CH4 observations from GOSAT. Geophysical Research Letters, 38(14). https://doi.org/10.1029/2011GL047888

CAPP (Canadian Association of Petroleum Producers). (2019a). 2017 Statistical data, Category: Land, Exploration, Drilling, Statistics: 01-04 Wells and Meters/Feet Drilled by Province. Retrieved September 12, 2019, from https://www.capp.ca/publications-andstatistics/statistics/statistical-handbook\#

CAPP (Canadian Association of Petroleum Producers). (2019b). June 2019 Capital Investment \& Drilling Forecast Update. Retrieved September 5, 2019, from https://www.capp.ca/economy/capital-investment/

CER (Canada Energy Regulator). (2020). Energy Information: Statistics \& Analysis. Retrieved February 5, 2020, from http://www.cer-rec.gc.ca/nrg/sttstc/index-eng.html

This article is protected by copyright. All rights reserved. 
Chan, E., Worthy, D. E. J., Chan, D., Ishizawa, M., Moran, M. D., Delcloo, A., \& Vogel, F. (2020). Eight-Year Estimates of Methane Emissions from Oil and Gas Operations in Western Canada Are Nearly Twice Those Reported in Inventories. Environmental Science \& Technology. https://doi.org/10.1021/acs.est.0c04117

Cooperative Global Atmospheric Data Integration Project. (2020). Multi-laboratory compilation of atmospheric methane data for the period 1957-2018;

obspack_ch4_1_GLOBALVIEWplus_v2.0_2020_04_24; NOAA Earth System Research Laboratory, Global Monitoring Division. Retrieved January 10, 2021, from http://dx.doi.org/10.25925/20200424

Diaconis, P., \& Efron, B. (1983). Computer-intensive methods in statistics. Scientic American, 248(5), 116-130.

Dils, B., Buchwitz, M., Reuter, M., Schneising, O., Boesch, H., Parker, R., et al. (2014). The Greenhouse Gas Climate Change Initiative (GHG-CCI): comparative validation of GHGCCI SCIAMACHY/ENVISAT and TANSO-FTS/GOSAT $\mathrm{CO}_{2}$ and $\mathrm{CH}_{4}$ retrieval algorithm products with measurements from the TCCON. Atmos. Meas. Tech., 7(6), 1723-1744. https://doi.org/10.5194/amt-7-1723-2014

Dlugokencky, E. J. (2021). Trends in atmospheric methane. NOAA/ESRL. Retrieved March 5, 2021, from https://www.esrl.noaa.gov/gmd/ccgg/trends_ch4/

Dlugokencky, E. J., Nisbet, E. G., Fisher, R., \& Lowry, D. (2011). Global atmospheric methane: budget, changes and dangers. Philosophical Transactions of the Royal Society A:

Mathematical, Physical and Engineering Sciences, 369(1943), 2058-2072.

https://doi.org/10.1098/rsta.2010.0341

ECCC (Environment and Climate Change Canada). (2017). Regulations Respecting Reduction in the Release of Methane and Certain Volatile Organic Compounds (Upstream Oil and Gas sector). Retrieved July 3, 2019, from http://www.gazette.gc.ca/rp-pr/p1/2017/2017-0527/html/reg1-eng.html

Frankenberg, C., Meirink, J. F., van Weele, M., Platt, U., \& Wagner, T. (2005). Assessing Methane Emissions from Global Space-Borne Observations. Science, 308(5724), 1010 LP 1014. https://doi.org/10.1126/science.1106644

Frankenberg, C., Meirink, J. F., Bergamaschi, P., Goede, A. P. H., Heimann, M., Körner, S., et al. (2006). Satellite chartography of atmospheric methane from SCIAMACHY on board ENVISAT: Analysis of the years 2003 and 2004. Journal of Geophysical Research: Atmospheres, 111(D7). https://doi.org/10.1029/2005JD006235

Ganesan, A. L., Schwietzke, S., Poulter, B., Arnold, T., Lan, X., Rigby, M., et al. (2019). Advancing Scientific Understanding of the Global Methane Budget in Support of the Paris Agreement. Global Biogeochemical Cycles, 33(12), 1475-1512. https://doi.org/10.1029/2018GB006065

GC (Government of Canada). (2020a). Canada's Official Greenhouse Gas Inventory: GHG_IPCC_Can_Prov_Terr.csv. Retrieved March 5, 2021, from 
https://open.canada.ca/data/en/dataset/779c7bcf-4982-47eb-af1b-a33618a05e5b

GC (Government of Canada). (2020b). Greenhouse Gas Reporting Program (GHGRP)-Facility Greenhouse Gas (GHG) Data. Data product: PDGES-GHGRP-GHGEmissionsGES-2004Present.csv. Retrieved February 12, 2021, from https://open.canada.ca/data/en/dataset/a8ba14b7-7f23-462a-bdbb-83b0ef629823

GoM (Petroleum Branch of Government of Manitoba). (2019). Petroleum: Interactive GIS Map Gallery. Technical Files and Maps: Well locations(zip). Retrieved August 20, 2019, from https://www.gov.mb.ca/iem/petroleum/gis/index.html

GoND (Government of North Dakota). (2019). North Dakota General Statistics: Drilling, Historical drilling statistics. Retrieved September 5, 2019, from https://www.dmr.nd.gov/oilgas/stats/statisticsvw.asp

GoS (Government of Saskatchewan). (2019). Oil and Gas News, Bulletins, Statistics and Reports: Saskatchewan Mining and Petroleum GeoAtlas. Retrieved August 20, 2019, from https://www.saskatchewan.ca/business/agriculture-natural-resources-and-industry/oil-andgas/oil-and-gas-news-and-bulletins

IPCC. (2013). Climate Change 2013: The Physical Science Basis. Contribution of Working Group I to the Fifth Assessment Report of the Intergovernmental Panel on Climate Change, Technical Report. In T. F. Stocker, D. Qin, G.-K. Plattner, M. Tignor, S. K. Allen, J. Boschung, et al. (Eds.) (p. 1585). Cambridge, United Kingdom and New York, NY, USA: Cambridge University Press.

Kai, F. M., Tyler, S. C., Randerson, J. T., \& Blake, D. R. (2011). Reduced methane growth rate explained by decreased Northern Hemisphere microbial sources. Nature, 476(7359), 194197. https://doi.org/10.1038/nature10259

Kivimäki, E., Lindqvist, H., Hakkarainen, J., Laine, M., Sussmann, R., Tsuruta, A., et al. (2019). Evaluation and Analysis of the Seasonal Cycle and Variability of the Trend from GOSAT Methane Retrievals. Remote Sensing . https://doi.org/10.3390/rs11070882

Kort, E. A., Frankenberg, C., Costigan, K. R., Lindenmaier, R., Dubey, M. K., \& Wunch, D. (2014). Four corners: The largest US methane anomaly viewed from space. Geophysical Research Letters, 41(19), 6898-6903. https://doi.org/10.1002/2014GL061503

Kuze, A., Suto, H., Nakajima, M., \& Hamazaki, T. (2009). Thermal and near infrared sensor for carbon observation Fourier-transform spectrometer on the Greenhouse Gases Observing Satellite for greenhouse gases monitoring. Applied Optics, 48(35), 6716-6733. https://doi.org/10.1364/AO.48.006716

Kuze, A., Suto, H., Shiomi, K., Kawakami, S., Tanaka, M., Ueda, Y., et al. (2016). Update on GOSAT TANSO-FTS performance, operations, and data products after more than 6 years in space. Atmos. Meas. Tech., 9(6), 2445-2461. https://doi.org/10.5194/amt-9-2445-2016

Lan, X., Tans, P., Sweeney, C., Andrews, A., Dlugokencky, E., Schwietzke, S., et al. (2019). Long-Term Measurements Show Little Evidence for Large Increases in Total U.S. Methane

This article is protected by copyright. All rights reserved. 
Emissions Over the Past Decade. Geophysical Research Letters, 46(9), 4991-4999. https://doi.org/10.1029/2018GL081731

Levin, I., Veidt, C., Vaughn, B. H., Brailsford, G., Bromley, T., Heinz, R., et al. (2012). No inter-hemispheric $\delta 13 \mathrm{CH} 4$ trend observed. Nature, 486(7404), E3-E4. https://doi.org/10.1038/nature11175

Mikaloff Fletcher, S. E., \& Schaefer, H. (2019). Rising methane: A new climate challenge. Science, 364(6444), 932 LP - 933. https://doi.org/10.1126/science.aax1828

MTBOGC (The Montana Board of Oil and Gas Conservation). (2019). Board of Oil and Gas Conservation: GIS Data, Wellsurface. Retrieved August 19, 2019, from http://www.bogc.dnrc.mt.gov/gisdata/WellSurface/

NDOGD (North Dakota Oil and Gas Division). (2019). North Dakota Oil and Gas Division: GIS Map Server, Wells. Retrieved August 18, 2019, from https://www.dmr.nd.gov/OaGIMS/viewer.htm

NIR (National Inventory Report). (2020). National Inventory Report 1990-2018: Greenhouse Gas Sources and Sinks in Canada. Canada's submission to the United Nations Framework Convention on Climate Change, Part 1, 2 and 3. Retrieved September 15, 2020, from https://unfccc.int/ghg-inventories-annex-i-parties/2020

Nisbet, E. G., Dlugokencky, E. J., \& Bousquet, P. (2014). Methane on the Rise-Again. Science, 343(6170), 493 LP - 495. https://doi.org/10.1126/science.1247828

Nisbet, E. G., Dlugokencky, E. J., Manning, M. R., Lowry, D., Fisher, R. E., France, J. L., et al. (2016). Rising atmospheric methane: 2007-2014 growth and isotopic shift. Global Biogeochemical Cycles, 30(9), 1356-1370. https://doi.org/10.1002/2016GB005406

Nisbet, E. G., Manning, M. R., Dlugokencky, E. J., Fisher, R. E., Lowry, D., Michel, S. E., et al. (2019). Very Strong Atmospheric Methane Growth in the 4 Years 2014-2017: Implications for the Paris Agreement. Global Biogeochemical Cycles, 33(3), 318-342. https://doi.org/10.1029/2018GB006009

NOAA/GML (National Oceanic and Atmospheric Administration Global Monitoring Laboratory). (2019). Global Greenhouse Gas Reference Network: Aircraft Program. Retrieved July 2, 2019, from https://www.esrl.noaa.gov/gmd/ccgg/aircraft/index.html

Parker, R. J., Webb, A., Boesch, H., Somkuti, P., Barrio Guillo, R., Di Noia, A., et al. (2020). A Decade of GOSAT Proxy Satellite CH4 Observations. Earth Syst. Sci. Data Discuss., 2020, 1-36. https://doi.org/10.5194/essd-2020-114

Pison, I., Ringeval, B., Bousquet, P., Prigent, C., \& Papa, F. (2013). Stable atmospheric methane in the 2000s: key-role of emissions from natural wetlands. Atmos. Chem. Phys., 13(23), 11609-11623. https://doi.org/10.5194/acp-13-11609-2013

Rigby, M., Montzka, S. A., Prinn, R. G., White, J. W. C., Young, D., O’Doherty, S., et al. (2017). Role of atmospheric oxidation in recent methane growth. Proceedings of the National Academy of Sciences, 114(21), 5373 LP - 5377.

This article is protected by copyright. All rights reserved. 
https://doi.org/10.1073/pnas.1616426114

Saunois, M., Bousquet, P., Poulter, B., Peregon, A., Ciais, P., Canadell, J. G., et al. (2016). The global methane budget 2000-2012. Earth Syst. Sci. Data, 8(2), 697-751.

https://doi.org/10.5194/essd-8-697-2016

Saunois, M., Stavert, A. R., Poulter, B., Bousquet, P., Canadell, J. G., Jackson, R. B., et al. (2020). The Global Methane Budget 2000-2017. Earth Syst. Sci. Data, 12(3), 1561-1623. https://doi.org/10.5194/essd-12-1561-2020

Schwietzke, S., Sherwood, O. A., Bruhwiler, L. M. P., Miller, J. B., Etiope, G., Dlugokencky, E. J., et al. (2016). Upward revision of global fossil fuel methane emissions based on isotope database. Nature, 538(7623), 88-91. https://doi.org/10.1038/nature19797

Sheng, J.-X., Jacob, D. J., Turner, A. J., Maasakkers, J. D., Benmergui, J., Bloom, A. A., et al. (2018). 2010-2016 methane trends over Canada, the United States, and Mexico observed by the GOSAT satellite: contributions from different source sectors. Atmos. Chem. Phys., 18(16), 12257-12267. https://doi.org/10.5194/acp-18-12257-2018

Statistics Canada. (2017a). Alberta [Province] and British Columbia [Province] (table). Census Profile. 2016 Census. Statistics Canada Catalogue no. 98-316-X2016001. Ottawa. Released November 29, 2017. Retrieved June 12, 2018, from https://www12.statcan.gc.ca/censusrecensement/2016/dp-pd/prof/index.cfm?Lang=E

Statistics Canada. (2017b). British Columbia [Province] and Canada [Country] (table). Census Profile. 2016 Census. Statistics Canada Catalogue no. 98-316-X2016001. Ottawa. Released November 29, 2017. Retrieved June 12, 2018, from https://www12.statcan.gc.ca/censusrecensement/2016/dp-pd/prof/index.cfm?Lang=E

Statistics Canada. (2017c). Canada [Country] and Canada [Country] (table). Census Profile. 2016 Census. Statistics Canada Catalogue no. 98-316-X2016001. Ottawa. Released November 29, 2017. Retrieved June 12, 2018, from https://www12.statcan.gc.ca/censusrecensement/2016/dp-pd/prof/index.cfm?Lang=E

Statistics Canada. (2017d). Saskatchewan [Province] and British Columbia [Province] (table). Census Profile. 2016 Census. Statistics Canada Catalogue no. 98-316-X2016001. Ottawa. Released November 29, 2017. Retrieved June 12, 2018, from https://www12.statcan.gc.ca/census-recensement/2016/dp-pd/prof/index.cfm?Lang=E

Stein, A. F., Draxler, R. R., Rolph, G. D., Stunder, B. J. B., Cohen, M. D., \& Ngan, F. (2015). NOAA's HYSPLIT Atmospheric Transport and Dispersion Modeling System. Bulletin of the American Meteorological Society, 96(12), 2059-2077. https://doi.org/10.1175/BAMSD-14-00110.1

Sweeney, C., Karion, A., Wolter, S., Newberger, T., Guenther, D., Higgs, J. A., et al. (2015). Seasonal climatology of $\mathrm{CO} 2$ across North America from aircraft measurements in the NOAA/ESRL Global Greenhouse Gas Reference Network. Journal of Geophysical Research: Atmospheres, 120(10), 5155-5190. https://doi.org/10.1002/2014JD022591

This article is protected by copyright. All rights reserved. 
Turner, A. J., Jacob, D. J., Benmergui, J., Wofsy, S. C., Maasakkers, J. D., Butz, A., et al. (2016). A large increase in U.S. methane emissions over the past decade inferred from satellite data and surface observations. Geophysical Research Letters, 43(5), 2218-2224. https://doi.org/10.1002/2016GL067987

Turner, A. J., Frankenberg, C., Wennberg, P. O., \& Jacob, D. J. (2017). Ambiguity in the causes for decadal trends in atmospheric methane and hydroxyl. Proceedings of the National Academy of Sciences, 114(21), 5367 LP - 5372. https://doi.org/10.1073/pnas.1616020114

Turner, A. J., Frankenberg, C., \& Kort, E. A. (2019). Interpreting contemporary trends in atmospheric methane. Proceedings of the National Academy of Sciences, 116(8), 2805 LP 2813. https://doi.org/10.1073/pnas.1814297116

WD (Western Economic Diversification Canada). (2018). About Western Canada. Retrieved June 12, 2018, from https://www.wd-deo.gc.ca/eng/243.asp

Wecht, K. J., Jacob, D. J., Frankenberg, C., Jiang, Z., \& Blake, D. R. (2014). Mapping of North American methane emissions with high spatial resolution by inversion of SCIAMACHY satellite data. Journal of Geophysical Research: Atmospheres, 119(12), 7741-7756. https://doi.org/10.1002/2014JD021551

Wunch, D., Toon, G. C., Blavier, J.-F. L., Washenfelder, R. A., Notholt, J., Connor, B. J., et al. (2011). The Total Carbon Column Observing Network. Philosophical Transactions of the Royal Society A: Mathematical, Physical and Engineering Sciences, 369(1943), 2087-2112. https://doi.org/10.1098/rsta.2010.0240

Wunch, D., Toon, G. C., Sherlock, V., Deutscher, N. M., Liu, X., Feist, D. G., \& Wennberg, P. O. (2015). The Total Carbon Column Observing Network's GGG2014 Data Version. Carbon Dioxide Information Analysis Center. Oak Ridge National Laboratory, Oak Ridge, Tennessee, USA. https://doi.org/doi:10.14291/tccon.ggg2014.documentation.R0/1221662

Wunch, D., Mendonca, J., Colebatch, O., Allen, N. T., Blavier, J.-F., Roche, S., et al. (2018). TCCON data from East Trout Lake, SK (CA), Release GGG2014.R1 [et120161007_20200602.public.nc]. Caltech DATA. https://doi.org/10.14291/TCCON.GGG2014.EASTTROUTLAKE01.R1

Figure 1. Canada's GHG and $\mathrm{CH}_{4}$ emissions at national and western regional levels (GC, 2020a; NIR, 2020). a) The line graph shows Canada's annual total GHG emissions from 2005 to 2018. Bar graph (right y axis) demonstrates the contribution (percent) from western provinces (BC, $\mathrm{AB}$ and SK) to the national total GHG. b-c) same as a) but b) refers to the total $\mathrm{CH}_{4}$ emissions (not including natural sources), and c) shows national and western Canadian fugitive $\mathrm{CH}_{4}$ emissions. d) This panel illustrates three western provinces' annual total energy production from 2007 to 2019. While calculating annual provincial total energy production, first monthly oil and natural gas production data were retrieved from the Energy Information section of the Canada Energy Regulator website (CER, 2020). Oil production includes crude oil and its equivalent, e.g., conventional light crude oil (BC, AB, SK), Alberta upgraded bitumen (only AB), condensate (BC, AB, SK), conventional heavy crude oil (only AB and SK), Alberta non-upgraded bitumen 
(only AB); and gas production refers to marketable natural gas production only. The annual provincial total energy production is obtained after converting annual oil and gas production into their equivalent energy contents following these conversions: $0.0373 \mathrm{GJ} / \mathrm{m}^{3}$ of natural gas and $39.5 \mathrm{GJ} / \mathrm{m}^{3}$ of crude oil (CER, 2020).

Figure 2. Three western Canadian provinces and their subdomains. The subdomains used for time series analysis are shown by rectangles (BK: Background zone; NE: Northeastern BC; AB: Alberta; SK: Saskatchewan-southern). We also created one subdomain (MN) covering Montana and North Dakota for $\mathrm{CH}_{4}$ trend analysis. Three NOAA GGGRN aircraft in situ measurement sites are also shown in blue circles (ESP, ETL, and DND). Geolocations of 2018 reported $\mathrm{CH}_{4}$ emission facilities (only oil and gas types) and their emission levels (Kt) are given by colored diamond symbols (GC, 2020b). Size of the diamond symbols and colorbar represent the emission quantity of the individual facility. Emissions from pipeline transportation systems are excluded. Historical oil and gas facility locations (up to July 2019) are also overlaid in dark (Canada) or light orange (US portion) (AER, 2019; BC OGC, 2019; GoM, 2019; GoND, 2019; GoS, 2019; MTBOGC, 2019; NDOGD, 2019). The yellow circle at the BK subdomain represents the receptor site where we performed back trajectory analysis of the year 2018 (see main text and Fig. S2 for further details). The base map is from Google Maps (Web Mercator projection).

Figure 3. Evaluation of the GOSAT proxy $\mathrm{XCH}_{4}$ retrievals (v9.0) with the coincident aircraft in situ vertical profiles and TCCON at the ETL site. a) Scatter plot between in situ based and GOSAT $\mathrm{XCH}_{4}$ (all available collocated observations), b) This panel illustrates the time series (2017-2019) of daily averaged paired GOSAT and TCCON XCH 4 at the ETL site. Regression parameters are shown in each panel.

Figure 4. Time series of GOSAT $\mathrm{XCH}_{4}$ data product over several subdomains for the period 2009-2019. The green line and red ' $x$ ' symbols in each plot represent long-term (2009-2019) mean and annual mean $\mathrm{XCH}_{4}$ of each subdomain, respectively. The long-term and annual means are quantified by averaging all valid daily observations for the respective periods in each subdomain. The magenta line (except NE) indicates the trend line of the annual mean $\mathrm{XCH}_{4}$. Trend with its uncertainty of each subdomain is shown in the upper left corner of each domain except NE. Trend in percent change per year is also given. The trend in $\% / y r$ is obtained by dividing the trend in $\mathrm{ppb} / \mathrm{yr}$ with the mean $\mathrm{XCH}_{4}$ of the corresponding subdomain and multiplied by 100 . Note we do not estimate $\mathrm{XCH}_{4}$ trend for the NE subdomain (see main text for detail).

Figure 5. Same as Fig. 4 but also illustrating annual mean $\mathrm{XCH}_{4}$ of the $\mathrm{BK}$ domain (green dots) to assess annual mean $\mathrm{XCH}_{4}$ in the source subdomain (red dots) relative to the $\mathrm{BK} \mathrm{XCH}_{4}$. The error bar is the standard deviation of the available observations of a given year. Again, we do not estimate $\mathrm{XCH}_{4}$ trend for the NE subdomain (see main text for detail).

Figure 6. Methane enhancements $\left(\triangle \mathrm{XCH}_{4}\right)$ above background with the GOSAT data product. Gray circles represent each individual residual, and red 'cross' mark corresponds to annual mean $\Delta \mathrm{XCH}_{4}$ quantified from monthly mean residuals of a year (see in the text). The error bar

This article is protected by copyright. All rights reserved. 
represents $1 \sigma$ of the monthly mean $\Delta \mathrm{XCH}_{4}$ of each year. The green straight zero reference line is given to assess frequencies of residuals relative to zero or negative differences.

This article is protected by copyright. All rights reserved. 


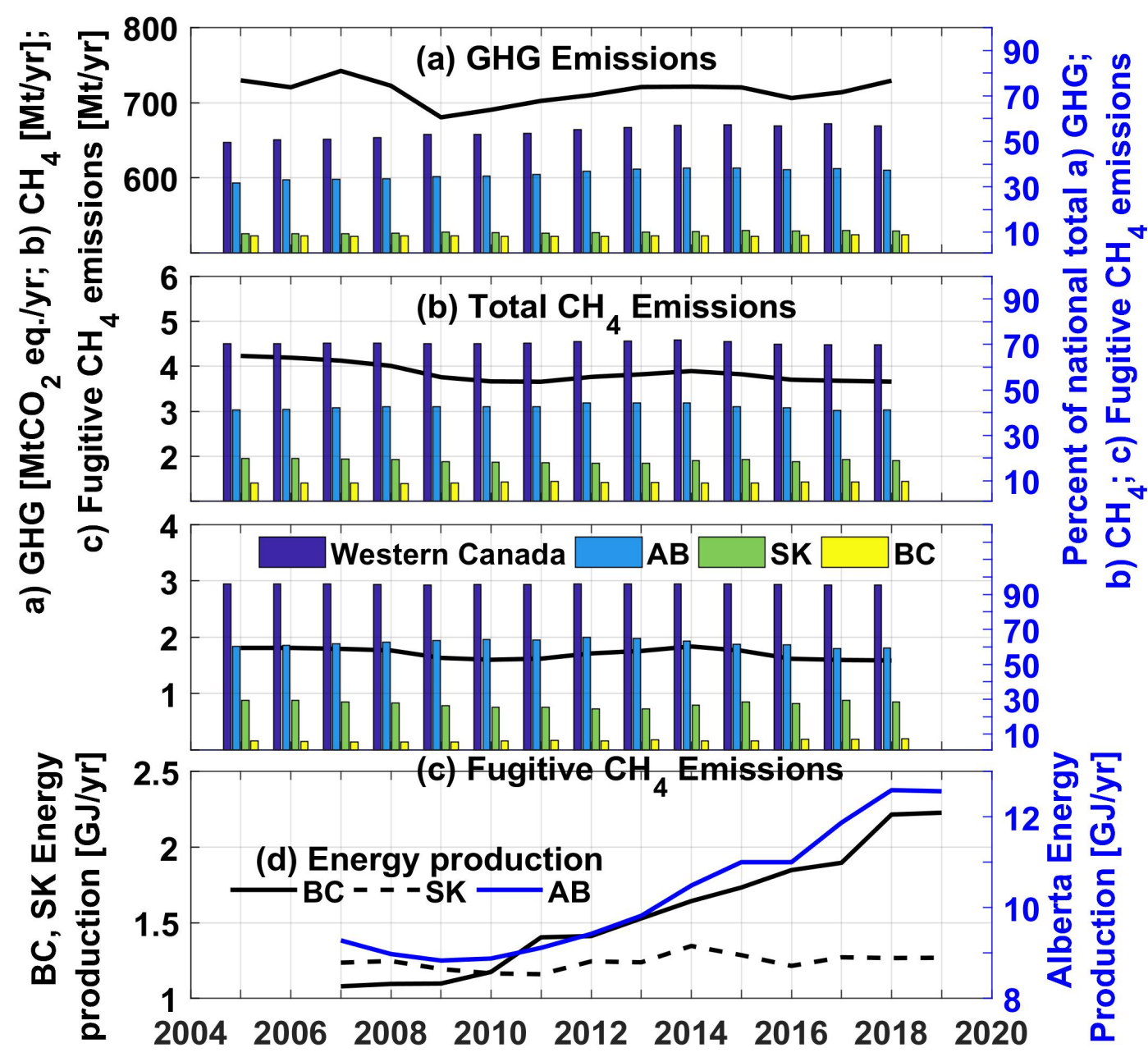

This article is protected by copyright. All rights reserved. 


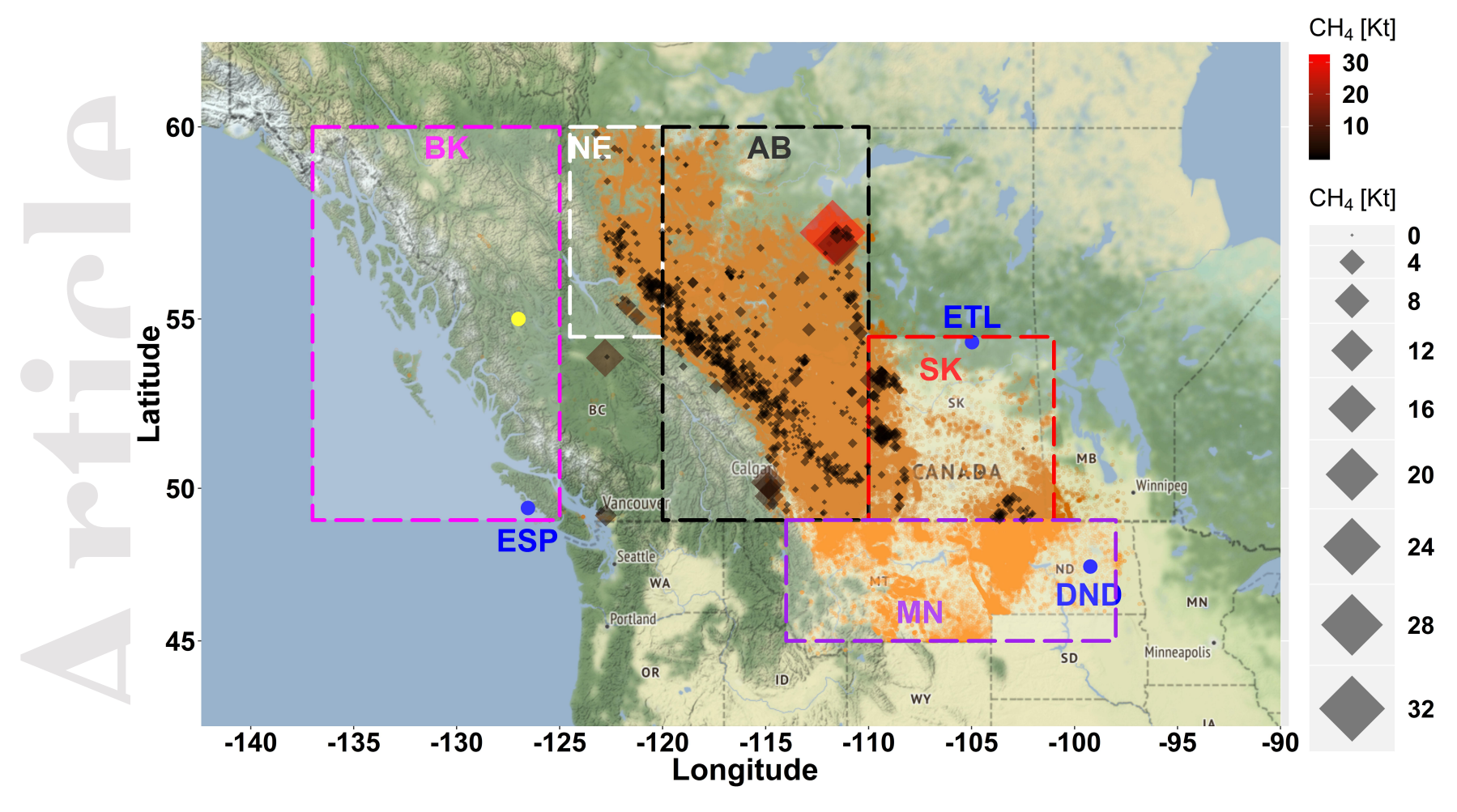

This article is protected by copyright. All rights reserved. 


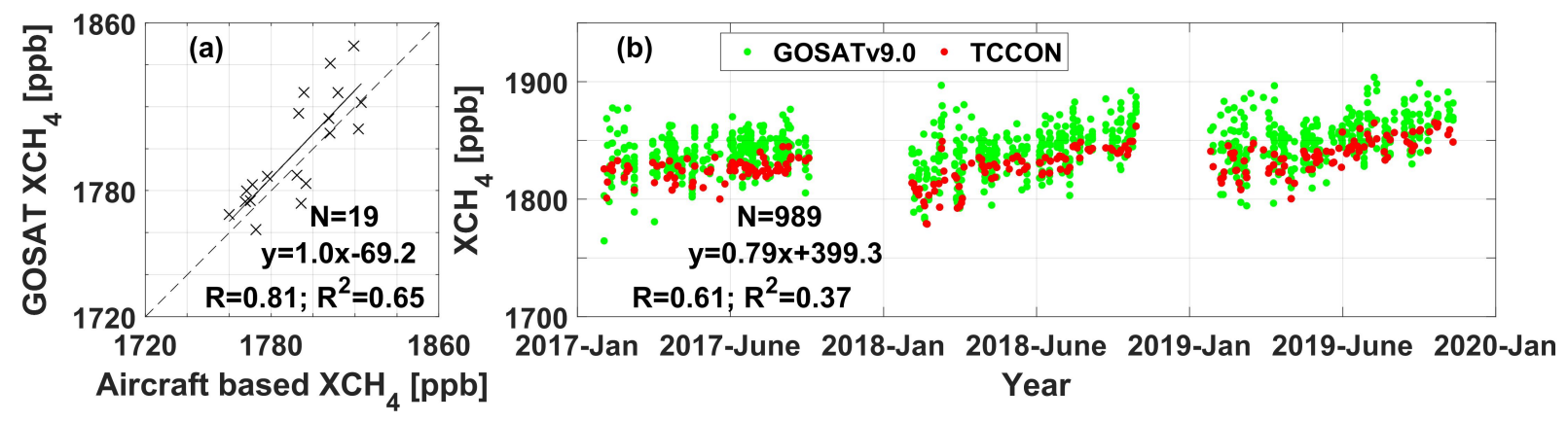

This article is protected by copyright. All rights reserved. 


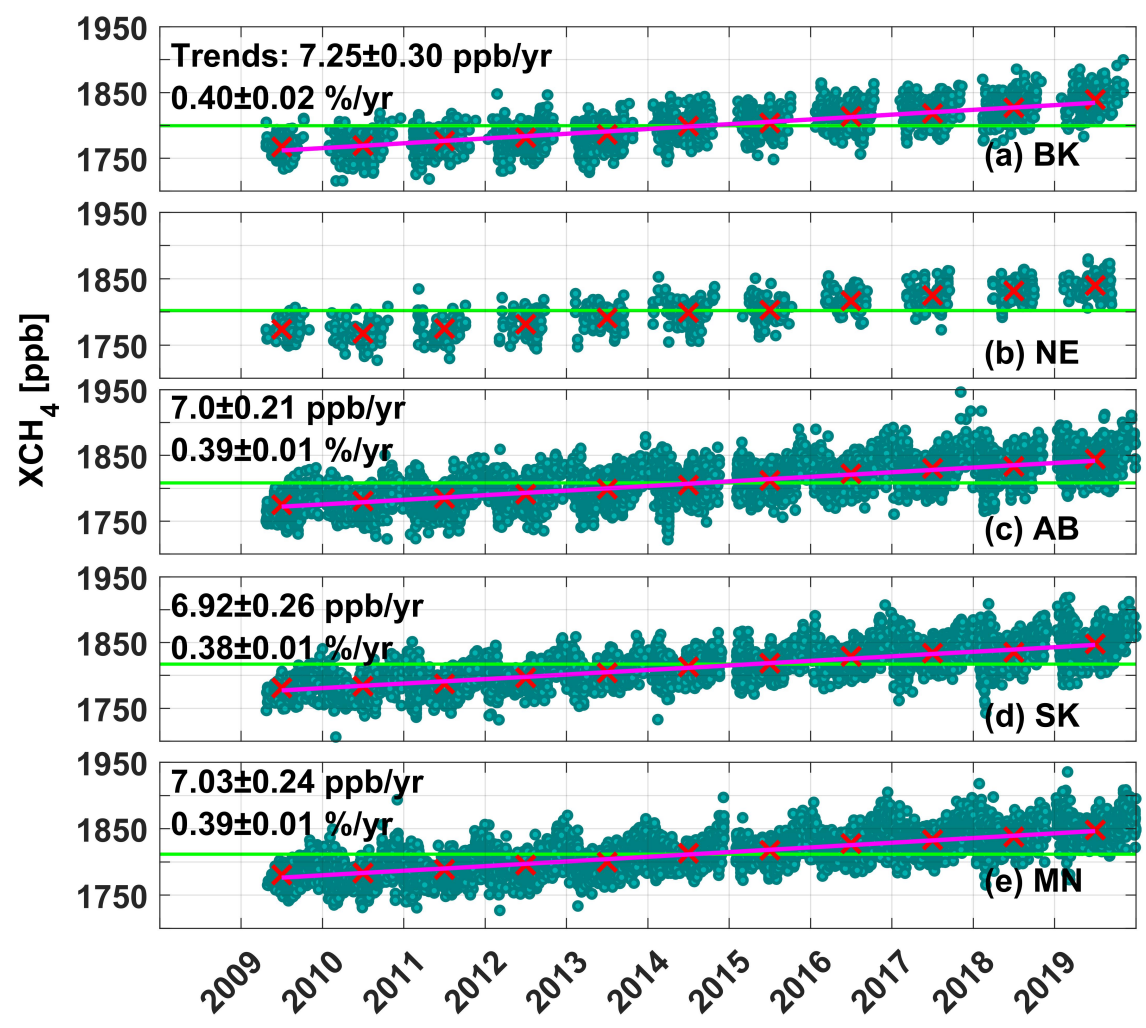

This article is protected by copyright. All rights reserved. 


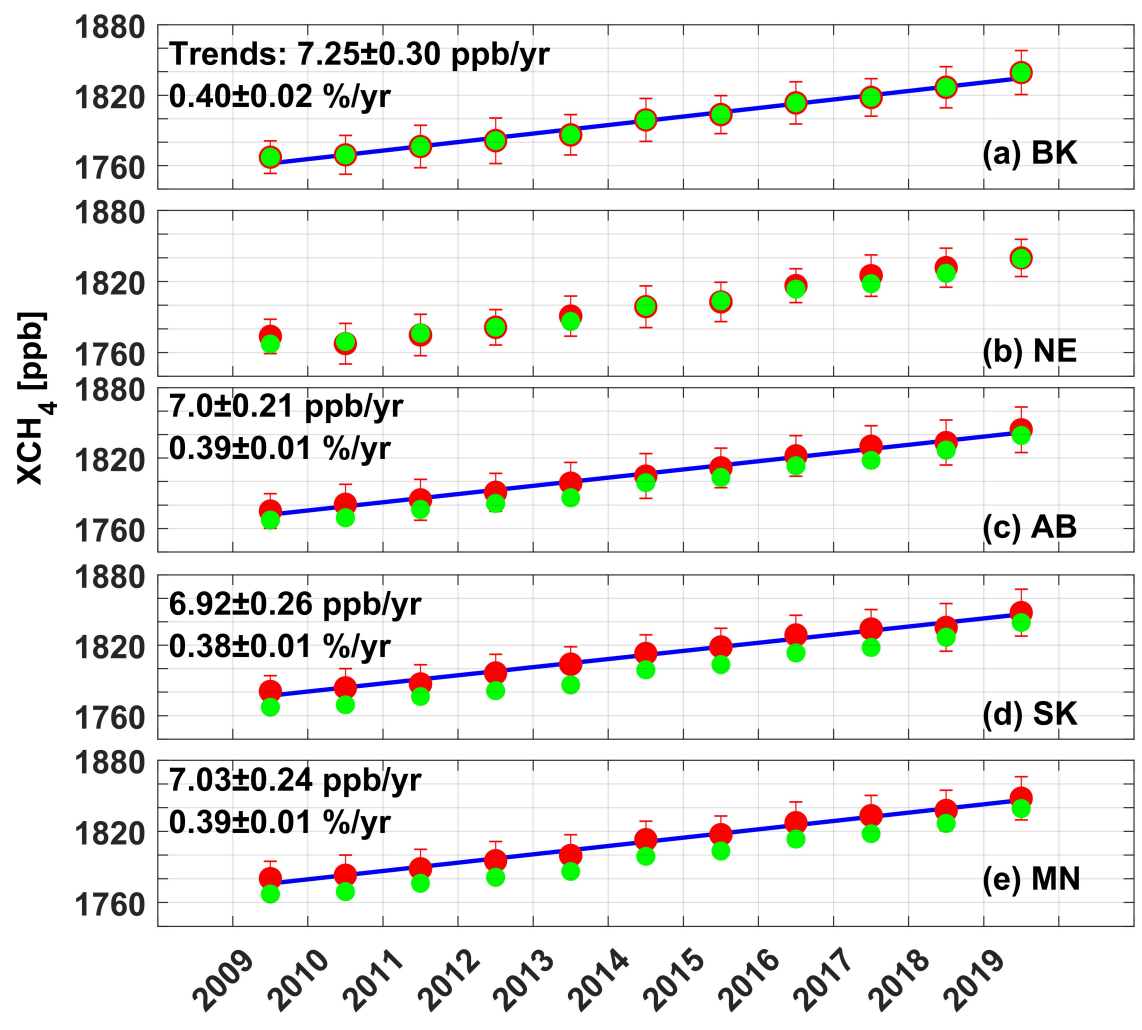

This article is protected by copyright. All rights reserved. 


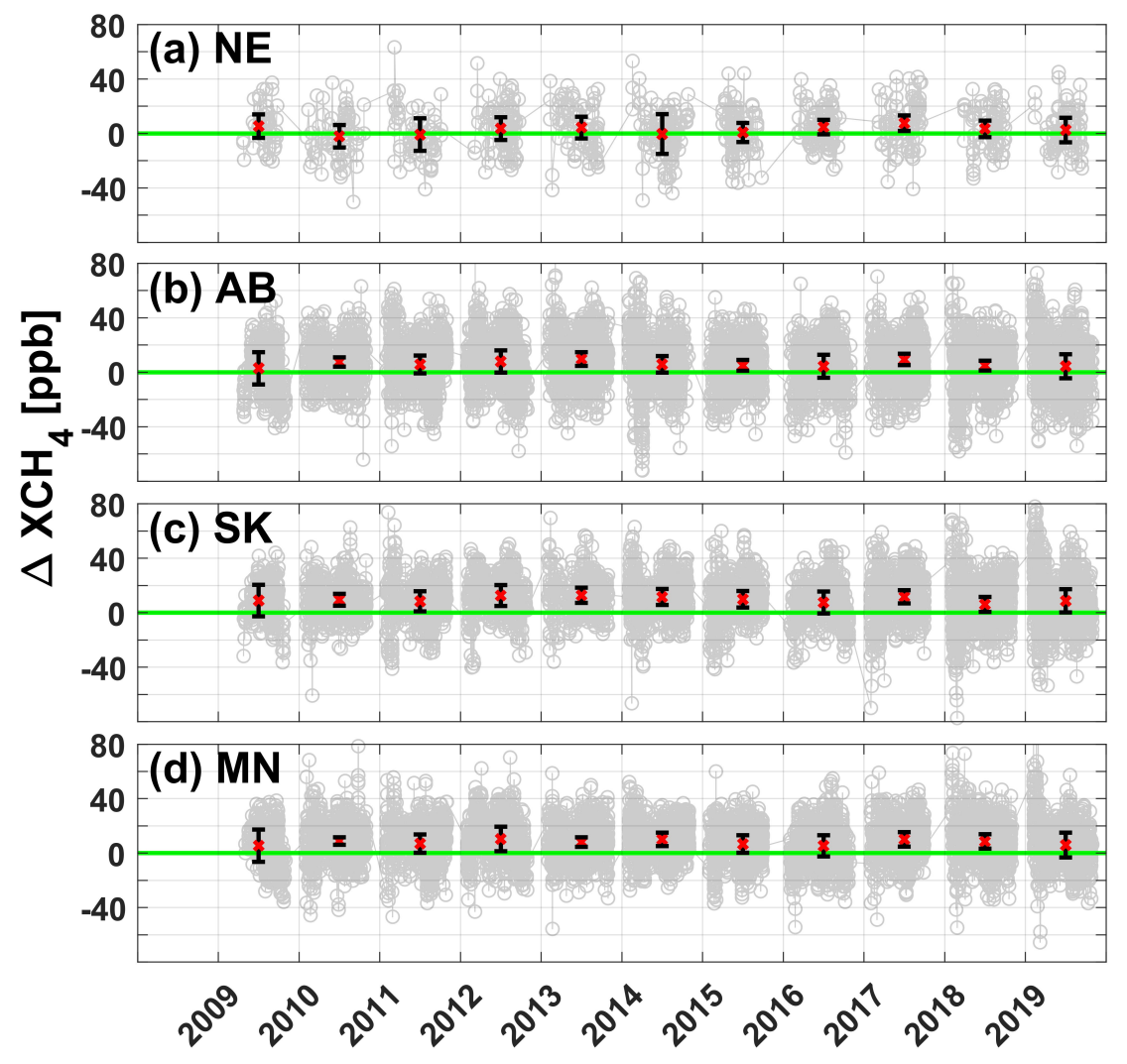

This article is protected by copyright. All rights reserved. 